\title{
PRODUTIVIDADE DA SOJA EM SEMEADURA DIRETA COM ANTECIPAÇÃO DA ADUBAÇÃO FOSFATADA E POTÁSSICA NA \\ CULTURA DE Eleusine coracana (L.) Gaertn.
}

\author{
Cláudio Roberto SEgATELLI
}

Dissertação apresentada à Escola
Superior de Agricultura "Luiz de
Queiroz", Universidade de São Paulo,
para obtenção do título de Mestre em
Agronomia, Área de Concentração:
Fitotecnia.

PIRACICABA

Estado de São Paulo - Brasil

Novembro - 2004 


\title{
PRODUTIVIDADE DA SOJA EM SEMEADURA DIRETA COM ANTECIPAÇÃO DA ADUBAÇÃO FOSFATADA E POTÁSSICA NA \\ CULTURA DE Eleusine coracana (L.) Gaertn.
}

\author{
CLÁUdio RoBERTo SEgATELLI \\ Engenheiro Agrônomo
}

Orientador: Prof. Dr. GIL MIGUEL DE SOUSA CÂMARA

\begin{abstract}
Dissertação apresentada à Escola Superior de Agricultura "Luiz de Queiroz”, Universidade de São Paulo, para obtenção do título de Mestre em Agronomia, Área de Concentração: Fitotecnia.
\end{abstract}

PIRACICABA

Estado de São Paulo - Brasil

Novembro - 2004 


\section{Dados Internacionais de Catalogação na Publicação (CIP) DIVISÃO DE BIBLIOTECA E DOCUMENTAÇÃO - ESALQ/USP}

Segatelli, Cláudio Roberto

Produtividade da soja em semeadura direta com antecipação da adubação fosfatada e potássica na cultura de Eleunise coracana (L.) Gaertn. / Cláudio Roberto Segatelli. - Piracicaba, 2004

$58 \mathrm{p}$.

Dissertação (Mestrado) - - Escola Superior de Agricultura Luiz de Queiroz, 2004.

Bibliografia.

1. Adubação 2. Capim pé-de-galinha 3. Fósforo 4. Potássio 5. Semeadura direta 6. Soja - Produtividade I. Título

CDD 633.34

"Permitida a cópia total ou parcial deste documento, desde que citada a fonte - O autor" 
A DEUS por este lindo “Universo”, pela nossa vida, saúde, sabedoria e por tudo que nos tem proporcionado...

A Nossa Senhora de Aparecida, pela presença e inspiração na minha vida e no trabalho, iluminando e protegendo o meu caminho...

Aos meus pais, Tertuliano Segatelli e Ivone Jordan Segatelli pelos ensinamentos de vida, dedicação, compreensão, amor...

Aos meus irmãos Aldo César Segatelli, Márcio José Segatelli e Tânia Mara Segatelli pelo companheirismo, carinho e compreensão nos momentos difíceis.

\section{OFEREÇO}

À vinda da minha filha Giovana Andressa de Araújo Segatelli, que com sua presença tem proporcionado grande alegria e sentido para minha vida, e à minha esposa Marilene de Araújo Segatelli pelo amor, apoio e compreensão nas horas divididas com este trabalho.

DEDICO

“A sabedoria não nos é dada, é preciso descobrí-la por nós mesmos depois de uma viagem que ninguém nos pode poupar ou fazer por nós”.

Marcel Proust, escritor francês, 1871-1922 


\section{AGRADECIMENTOS}

Agradeço de forma muito especial às pessoas e instituições que tornaram possível a realização deste trabalho:

Ao Prof. Dr. Gil Miguel de Sousa Câmara pela orientação, compreensão, respeito e valiosa amizade durante esses anos de convívio;

Aos professores Dr $^{\mathrm{a}}$ Sônia Maria de Stéfano Piedade, Dr. Daniel Furtado Ferreira, Dr. Antonio Augusto Franco Garcia e Dr. José Baldin Pinheiro pela ajuda na execução e interpretação das análises estatísticas;

Aos professores do curso de Pós-graduação em Fitotecnia da USP/ESALQ, pelos grandiosos ensinamentos;

Aos Professores do Departamento de Genética pelo apoio, compreensão, companheirismo, profissionalismo e oportunidade para que eu pudesse aprender e enriquecer meus conhecimentos, onde através desses conhecimentos adquiridos poderei retribuí-los com uma melhor qualidade de trabalho;

Aos colegas pós-graduandos Eng ${ }^{\circ}$ Agr $^{\circ}$ Paulo Eduardo Argenton, Eng ${ }^{\circ}$ Agr $^{\circ}$ Marcelo José Mortati Gullo pelo apoio e amizade, em especial à Doutoranda Lília Sichmann Heiffig, que muito tem colaborado com este trabalho; 
À Dr $^{\mathrm{a}}$ Mônica Cagnin Martins pela colaboração e apoio na execução deste trabalho, e pela verdadeira amizade e profissionalismo;

Ao colega Eros Artur Bohac Francisco, pela colaboração, apoio e amizade;

Ao companheiro de trabalho Aparecido da Silva pelo companheirismo, apoio, dedicação e compreensão neste período;

À Cooperativa dos Plantadores de Cana do Estado de São Paulo, em especial ao colega Eng ${ }^{\circ}$ Agr $^{0}$ Marcos Farhat, gerente do Departamento Técnico, pela realização das Análises Laboratoriais de Solo e pela sincera amizade;

Aos funcionários do Departamento de Genética, que de alguma forma colaboraram com este trabalho, principalmente aqueles que me apoiaram e incentivaram neste desafio;

Aos funcionários da Estação Experimental Anhembi, Manoel Antunes, Francisco de Assis Ribeiro, Carlos Baltazar, Isaías Monteiro, Alexandre de Camargo Campos, em especial José Monteiro, pelo apoio e pelo companheirismo;

Aos estagiários do Grupo de Pesquisas em Oleaginosas (GPO), Daniel Botelho Pedroso, Fernando Ferraz Barros, Luciana Aparecida Marques, Samuel Sadao Nacamura, Márcia Moreira Ayres de Souza, Melissa Pin Luchetti, Fábio Jordão Rocha, Marcos Antonio Mattos, Luciana Montebello de Oliveira, Renato Nogueira Rodrigues Alves Filho pela colaboração e amizade;

À gerência agrícola do Departamento de Produção Vegetal da USP/ESALQ, especialmente, ao colega Edson R. Teramoto e aos funcionários Ananias Ferreira de Sousa, César Renato Galvão Desiderio, Edson Ademir de Moraes, Adilson de Jesus Teixeira, Adilson Aparecido Dias, Antonio Pereira de Andrade, Cláudio do Espírito 
Santo Ferraz, Wilson Góes da Silva, Daniel Luiz Theodoro, Claudinei Martins Valério, José dos Reis Lopes, José Soares de Almeida, Laerte Tibério, João Rodrigues, Marcelo Valente Batista, Rodrigo Camargo Campos, Osvaldo de Jesus Pelissari, pelo apoio e auxílio nas atividades do experimento em campo;

À Enga . Agra . Responsável pelo Laboratório de Análise de Sementes da USP/ESALQ - Helena Maria C. Pescarin Chamma pelas sugestões e apoio nas atividades realizadas;

À secretária do Departamento de Produção Vegetal da USP/ESALQ, Silvia Borghesi e aos funcionários Celestino Alves Ferreira, Maria Aparecida Teixeira Soledade e Luciane Aparecida Lopes Toledo;

A Sementes Brejeiro e Agronorte Pesquisa e Sementes Ltda pelo fornecimento das sementes utilizadas no experimento;

À USP/ESALQ pela oportunidade concedida para que eu pudesse desenvolver, evoluir e enriquecer meus conhecimentos... 


\section{SUMÁRIO}

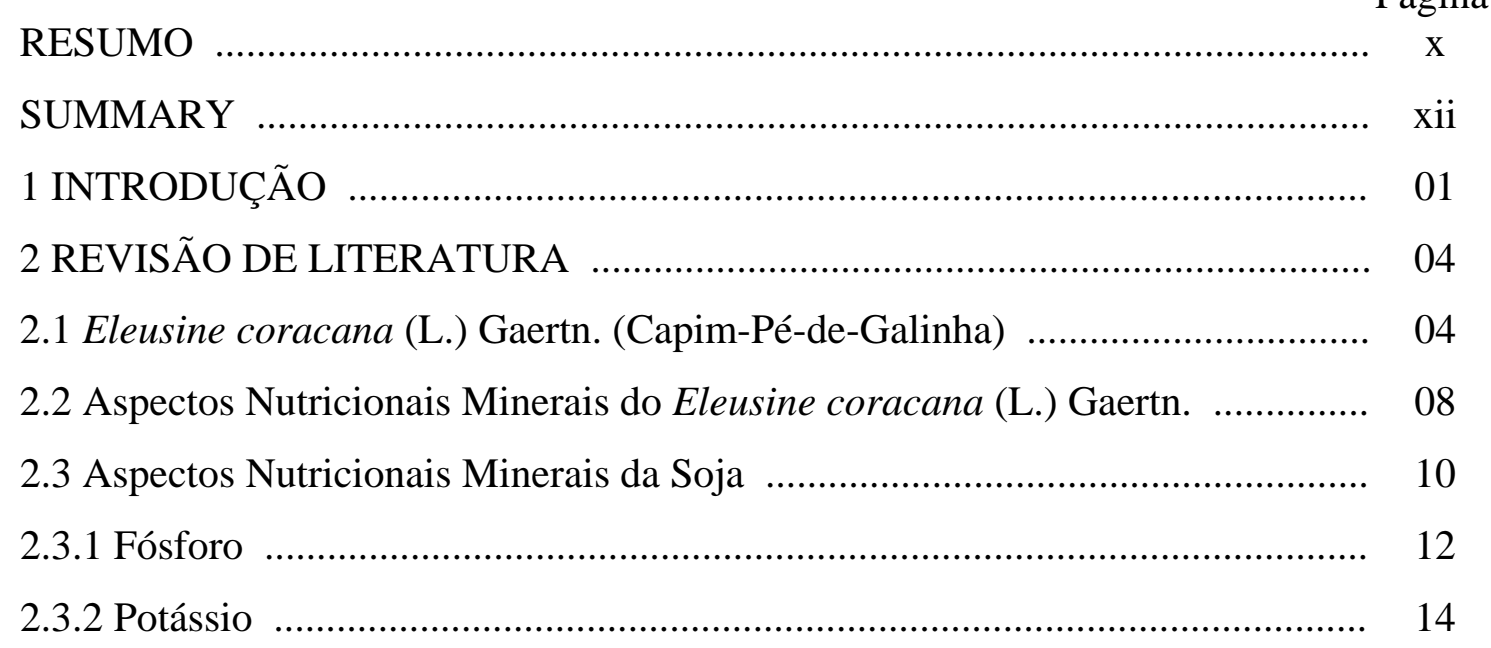

2.4 Adubação Antecipada de P e K em Agroecossistemas ................................. 17

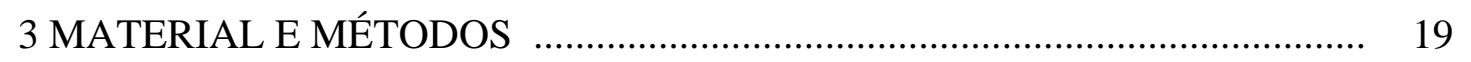

3.1 Local e Época da Realização do Experimento ............................................ 19

3.2 Características e Manejo do Solo .............................................................. 19

3.3 Características dos Cultivares .............................................................. 21

3.4 Delineamento e Unidade Experimental .................................................... 22

3.5 Preparo da Área, Instalação e Condução do Experimento ............................. 24

3.6 Colheita do Experimento ....................................................................... 26

3.7 Parâmetro Avaliado no Capim-pé-de-galinha .............................................. 26

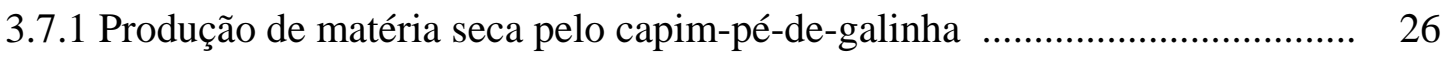

3.8 Parâmetros Avaliados na Soja ................................................................. 26

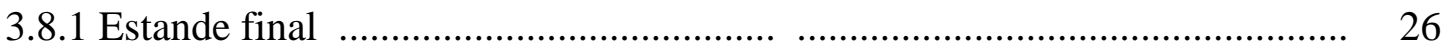

3.8.2 Altura final de planta ........................................................................ 26 
3.8.3 Porcentagem de plantas com haste verde .................................................. 26

3.8.4 Grau de acamamento ......................................................................... 27

3.8.5 Número de ramificações por planta ............................................................ 27

3.8.6 Número de vagens chochas por planta ....................................................... 27

3.8.7 Número de vagens de 3 cavidades com 3 grãos …………………………... 27

3.8.8 Número de vagens de 3 cavidades com 2 grãos .......................................... 27

3.8.9 Número de vagens de 3 cavidades com 1 grão ............................................. 27

3.8.10 Número de vagens de 2 cavidades com 2 grãos ........................................ 28

3.8.11 Número de vagens de 2 cavidades com 1 grão ........................................... 28

3.8.12 Número de vagens de 1 cavidade com 1 grão ............................................ 28

3.8.13 Número total de vagens por planta ......................................................... 28

3.8.14 Número total de grãos por planta ............................................................ 28

3.8.15 Peso de grãos por planta ....................................................................... 28

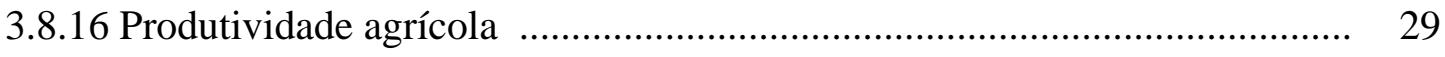

3.8.17 Peso de 1000 grãos .............................................................................. 29

4 RESULTADOS E DISCUSSÃO ............................................................... 32

4.1 Considerações Iniciais ........................................................................... 32

4.1.1 Considerações sobre a precipitação pluvial e a temperatura média do ar durante o período de experimentação ..................................................................... 32

4.2 Produtividade de Matéria Seca do Capim-pé-de-galinha ................................ 34

4.3 Parâmetros Relativos a Pré-Colheita da Soja ................................................. 36

4.4 Parâmetros Relativos aos Componentes da Produção de Soja .......................... 38

4.4.1 Número de ramificações, vagens chochas e total de vagens por planta ....... 38

4.4.2 Número e peso total de grãos por planta ....................................................... 40

4.4.3 Número de vagens de 3 cavidades com 3, 2 e 1 grão .................................... 41

4.4.4 Número de vagens de 2 cavidades com 2 e 1 grão e número de vagens de 1 cavidade com 1 grão ..........................................................................................

4.5 Produtividade Agrícola da Soja e Peso de Mil Grãos ...................................... 44

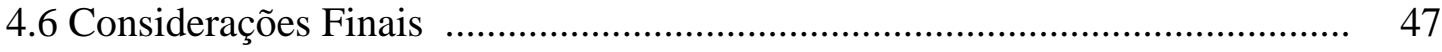

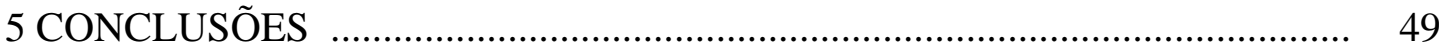


REFERÊNCIAS BIBLIOGRÁFICAS _.............................................................. 50

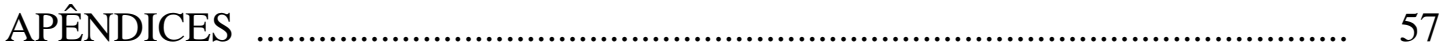




\title{
PRODUTIVIDADE DA SOJA EM SEMEADURA DIRETA COM ANTECIPAÇÃO DA ADUBAÇÃo FOSFATADA E POTÁSSICA NA CULTURA DE Eleusine coracana (L.) Gaertn.
}

\author{
Autor: CLÁUDIO ROBERTO SEGATELLI \\ Orientador: Prof. Dr. GIL MIGUEL DE SOUSA CÂMARA
}

\section{RESUMO}

O presente experimento teve por objetivo avaliar a produtividade agrícola da soja em sistema de semeadura direta com antecipação da adubação fosfatada e potássica na cultura de Eleusine coracana, sustentando-se a hipótese de que a produtividade da soja não é reduzida devido à antecipação da adubação de base para a cultura de Eleusine coracana (L.) Gaertn. (capim-pé-de-galinha). O experimento foi conduzido na Estação Experimental Anhembi, Escola Superior de Agricultura "Luiz de Queiroz” (USP/ESALQ), no município de Piracicaba-SP, localizada à margem direita do Rio Tietê, na cabeceira da represa de Barra Bonita-SP, entre as coordenadas $22^{\circ} 45^{\prime}$ e $22^{\circ}$ 50 ' de latitude Sul, e $48^{\circ} 00^{\prime}$ e $45^{\circ} 05^{\prime}$ de longitude Oeste, durante o ano agrícola de 2001/2002, em LATOSSOLO AMARELO Distrófico. A adubação, segundo a recomendação oficial para o estado de São Paulo, consistiu da aplicação de $90 \mathrm{~kg}$ de $\mathrm{P}_{2} \mathrm{O}_{5} \mathrm{ha}^{-1}, 50 \mathrm{~kg}$ de $\mathrm{K}_{2} \mathrm{O}$ ha $^{-1}$ e de micronutrientes (Co, Cu, Fe, Mn, Mo e Zn). O experimento adotou delineamento em blocos completos ao acaso com três repetições. Os tratamentos experimentais consistiram em diferentes níveis de antecipação da adubação da soja, para a cultura do capim-pé-de-galinha, totalizando 12 tratamentos: $\mathrm{T} 1=$ 
nenhuma adubação; T2 = adubação convencional na soja; T3 = 50\% de K, no capim-péde-galinha; T4 = 100\% de K, no capim-pé-de-galinha; T5 = 50\% de P, no capim-pé-degalinha; T6 = 50\% de P e K, no capim-pé-de-galinha; T7 = 50\% de P e $100 \%$ de K, no capim-pé-de-galinha; T8 = 100\% de P, no capim-pé-de-galinha; T9 = 100\% de P e 50\% de K, no capim-pé-de-galinha; T10 = 100\% de P e K, no capim-pé-de-galinha; T11 = 100\% de P e K + micronutrientes, no capim-pé-de-galinha; T12 = adubação foliar com micronutrientes, no capim-pé-de-galinha. As características avaliadas foram: a) capim pé-de-galinha: produção de matéria seca; b) soja: estande final, altura final de planta, porcentagem de plantas com haste verde, grau de acamamento, número de ramificações por planta, número de vagens chochas por planta, número de vagens de 3 cavidades com 3, 2 e 1 grão, número de vagens de 2 cavidades com 2 e 1 grão, número de vagens de 1 cavidade com 1 grão, número total de vagens por planta, número total de grãos por planta, peso de grãos por planta, peso de mil grãos e produtividade agrícola. As principais conclusões são: a) a adubação fosfatada e potássica da cultura da soja, antecipadas parcial ou totalmente para a semeadura do capim Eleusine coracana (L.) Gaertn., podem incrementar a produtividade agrícola de matéria seca do capim-pé-degalinha; b) a antecipação parcial ou total das adubações fosfatada e potássica da soja para a semeadura do Eleusine coracana (L.) Gaertn., nas condições em que foi instalado o experimento, não reduz a produtividade agrícola de grãos de soja; c) Trabalhos de pesquisa agronômica envolvendo estudos sobre adubação de agroecossistemas devem ser incentivados. 


\title{
SOYBEAN YIELD WITH PHOSPHORUS AND POTASSIUM PRE- FERTILIZATION ON THE Eleusine coracana (L.) Gaertn. IN A NO-TILLAGE SYSTEM
}

\author{
Author: CLÁUDIO ROBERTO SEGATELLI \\ Adviser: Prof. Dr. GIL MIGUEL DE SOUSA CÂMARA
}

\section{SUMMARY}

The present research evaluated soybean yield in a no-tillage system with previous potassium and phosphorus fertilization on the Eleusine coracana (L.) Gaertn. crop. The hypothesis was that soybean yield does not decrease due to previous fertilization on the Eleusine coracana (L.) Gaertn. (finger millet) crop. The experiment was carried out during the 2001/2002 growing season at the Estação Experimental Anhembi, Escola Superior de Agricultura "Luiz de Queiroz” (USP/ESALQ), in Piracicaba, São Paulo. The area is located at the right side bank of the Tietê river, at the beginning of the Barra Bonita Dam, between the coordinates $22^{\circ} 45^{\prime}$ and $22^{\circ} 50^{\prime}$ latitude south, and $48^{\circ} 00^{\prime}$ and $45^{\circ} 05^{\prime}$ longitude west, in an Oxisol. The soybean fertilization was done according to the São Paulo State offical recommendation: $90 \mathrm{~kg}$ of $\mathrm{P}_{2} \mathrm{O}_{5} \mathrm{ha}^{-1}$, $50 \mathrm{~kg}$ of $\mathrm{K}_{2} \mathrm{O} \mathrm{ha}^{-1}$ and micronutrients ( $\mathrm{Co}, \mathrm{Cu}, \mathrm{Fe}, \mathrm{Mn}, \mathrm{Mo}$ and $\mathrm{Zn}$ ). The experiment designed in randomized complete blocks, with three replicates. The treatment consisted of differents levels of soybean pre-fertilization, on the finger millet crop, totalizing 12 treatments: $\mathrm{T} 1=$ no fertilization; $\mathrm{T} 2=$ conventional fertilization, on Soybean; $\mathrm{T} 3=50 \%$ of $\mathrm{K}$, on finger 
millet; $\mathrm{T} 4=100 \%$ of $\mathrm{K}$, on finger millet; $\mathrm{T} 5=50 \%$ of $\mathrm{P}$, on finger millet; $\mathrm{T} 6=50 \%$ of both $\mathrm{P}$ and $\mathrm{K}$, on finger millet; $\mathrm{T} 7=50 \%$ of $\mathrm{P}$ and $100 \%$ of $\mathrm{K}$, on finger millet; $\mathrm{T} 8=$ $100 \%$ of $\mathrm{P}$, on finger millet; $\mathrm{T} 9=100 \%$ of $\mathrm{P}$ and $50 \%$ of $\mathrm{K}$, on finger millet; $\mathrm{T} 10=$ $100 \%$ of $\mathrm{P}$ and $\mathrm{K}$, on finger millet; $\mathrm{T} 11=100 \%$ of $\mathrm{P}$ and $\mathrm{K}+$ micronutrients, on finger millet; $\mathrm{T} 12$ = fertilization with micronutrients, on finger millet. The evaluated chacaracters were: a) finger millet: dry matter production; b) soybean: final stand, final plant height, percentage of plants with green stems, bending, number of branches per plant, number of empty pods, number of pods with 3 cavities with 3, 2 and 1 grain, number of pods with 2 cavities with 2 and 1 grain, number of pods with 1 cavity with 1 grain, total number of pods per plant, total number of grains per plant, grain weight per plant, mass of 1,000 grains and total yield. The main conclusions are: a) phosphorus and potassium pre-fertilization on soybean, totally or partial applied to the Eleusine coracana (L.) Gaertn. crop, can increase the finger millet dry matter yield; b) total or partial pre-fertilization of soybean phosphorus and potassium on Eleusine coracana (L.) Gaertn. crop, under experimental conditions tested, does not decrease the soybean yield; c) more studies about fertilization in agroecosystems should be encouraged. 


\section{INTRODUÇÃO}

A soja, Glycine max (L.) Merrill, é uma das mais importantes oleaginosas do mundo. Nos últimos anos, principalmente com a abertura de novas áreas sob vegetação de cerrado, o Brasil passou a ser um importante produtor de soja, tendo apresentado na safra 2002/2003 a produção total de 52 milhões de toneladas de grãos, em uma área colhida de 18 milhões de hectares, com produtividade média de $2.816 \mathrm{~kg} \mathrm{ha}^{-1}$ (Conab, 2004). Atualmente, a cultura da soja está sendo cultivada em praticamente todo o território nacional, apresentando, em algumas regiões brasileiras, médias de rendimento superiores às obtidas pela soja norte-americana.

Dentro da constituição do planeta, apenas $25 \%$ são terras, onde se encontram tanto áreas agricultáveis como regiões inóspitas. Do total, uma pequena porcentagem ainda não é explorada, ocupando a maior parte dessas áreas, o cerrado brasileiro. Os cerrados abrangem principalmente a região Centro-Oeste, parte da região Norte, Nordeste e Sudeste, ocupando uma área aproximada de 204 milhões de hectares, dos quais 50 milhões são de terras aráveis, ou seja, cerca de 28\%. Estas áreas apresentam condições favoráveis de clima, sem limitações de temperatura e radiação solar, mas apresentam problemas de distribuição de chuvas (estacionalidade) e fertilidade de solos (elevada acidez e saturação de alumínio), além de alta suscetibilidade à erosão.

O cultivo convencional, com intensiva exploração do solo, não tem mantido a estrutura física, a fertilidade e a atividade biológica dos solos do cerrado. As chuvas intensas de verão, característica da região, encontram solos desestruturados fisicamente, com baixa capacidade de infiltração e retenção de água, favorecendo a ocorrência sistemática do processo erosivo. 
A implantação de um sistema de produção menos agressivo ao solo, como o Sistema de Semeadura Direta, tão ou mais produtivo que os sistemas convencionais de produção, vem de encontro às necessidades do cerrado, evitando a degradação excessiva e impedindo a deterioração dos solos.

Além da necessidade de se desenvolver novas técnicas de cultivo como o Sistema de Semeadura Direta e de se obter novos materiais genéticos adaptados a essas condições, faz-se necessário o melhoramento de outras técnicas culturais, como por exemplo, os métodos de adubação das culturas.

Atualmente preconiza-se e até já se observa, ainda de forma insipiente, a adoção da técnica conhecida como "adubação de sistema” ou “adubação antecipada do agroecossistema”. Esta técnica consiste na antecipação da aplicação total ou parcial da quantidade de fertilizante dimensionada para uma determinada cultura de verão, promovendo-se a antecipação na forma de adubação de uma cultura antecessora, sobre a qual será efetuada a semeadura direta da cultura de verão ou, na forma de adubação a lanço, antes da semeadura da cultura de verão.

Com a adubação antecipada do agroecossistema, conseqüentemente, também são antecipadas a manipulação e a movimentação dos fertilizantes, o que permite que a operação de semeadura ocorra de forma mais rápida.

Outra vantagem da adubação antecipada sobre uma cultura antecessora, normalmente para formação de palha ou cobertura visando a semeadura direta, reside em maior incremento na produção de matéria orgânica para o agroecossistema, melhorando a conservação do solo, a manutenção de umidade e a reciclagem de nutrientes, que via mineralização da matéria orgânica, passarão às formas disponíveis à cultura de verão em sucessão.

Atualmente, nos agroecossistemas sobre solos de cerrado das regiões CentroOeste e Centro-Norte do Brasil predomina, em larga escala, a cultura da soja no verão e a cultura do milheto como cultura de entressafra formadora de palha para semeadura direta.

Em face aos poucos conhecimentos sobre os efeitos da prática da adubação antecipada na cultura da soja e do potencial de Eleusine coracana (L.) Gaertn. (capim- 
pé-de-galinha) como cultura de cobertura, realizou-se este trabalho com o objetivo de avaliar a produtividade da soja em sistema de semeadura direta com antecipação da adubação fosfatada e potássica na cultura de Eleusine coracana, sustentando-se a hipótese de que a produtividade da soja não é reduzida devido à antecipação da adubação de base para a cultura do Eleusine coracana (L.) Gaertn. (capim-pé-degalinha). 


\section{REVISÃO DE LITERATURA}

\subsection{Eleusine coracana (L.) Gaertn. (Capim-Pé-de-Galinha)}

A espécie Eleusine coracana (L.) Gaertn., conhecida na língua inglesa como “finger millet”, teve sua origem em Uganda, leste da África, aonde a mesma vem sendo cultivada há mais de 5.000 anos. Provavelmente foi introduzida na Índia há 3.000 anos, e, embora seja encontrada em muitos outros países tropicais, possui pouca importância fora da África e da Índia (Odelle, 1994).

No Brasil, vem sendo denominada capim-pé-de-galinha, porém, sem nenhuma relação com a planta daninha Eleusine indica (L.).

Em Zâmbia, segundo Agrawal et al. (1994), o grão é utilizado para alimentar pássaros durante os meses de dezembro e janeiro, a fim de prevenir danos às culturas em emergência. Segundo Mushonga et al. (1994), no Zimbabwe o grão é utilizado na alimentação de aves e suínos, enquanto o grão e a forragem são utilizados na alimentação de bovinos, ovinos e caprinos. O autor também afirma ser ingrediente de muitos pratos tradicionais da alimentação humana, como é o caso da utilização da farinha no preparo de mingaus. No Kenya, segundo Mitaru et al. (1994), o Eleusine coracana como alimento, é utilizado principalmente para preparar mingaus.

Na Etiópia, segundo Mulatu e Kebede (1994), as regiões produtoras são dependentes da cultura, por se desenvolver relativamente bem em anos secos e garantir alimento em tempo de escassez.

Em 1998 a produção mundial de grãos de milheto foi de 26,4 milhões de toneladas proveniente de 36 milhões de hectares colhidos, resultando em produtividade média mundial de apenas $729 \mathrm{~kg} \mathrm{ha}^{-1}$. Desse volume mundial, 49\% foram produzidos na 
África com liderança da Nigéria que produziu 20,7\% do total mundial. A Ásia produziu 45\% com liderança da Índia com 30,7\% do volume mundial produzido em 1998 (FAO Production Yearbook, 1999).

No Brasil, a espécie Eleusine coracana (L.) Gaertn. foi introduzida no ano de 1995, no estado de Mato Grosso, com interesse dos agricultores em utilizá-la como cultura formadora de palha. Atualmente trata-se de uma espécie gramínea melhorada pelo homem para ser utilizada como planta forrageira nas regiões da fronteira agrícola brasileira (baixas latitudes) e que, recentemente, vem sendo utilizada como cultura formadora de palha para a semeadura direta da cultura da soja.

Segundo Francisco (2002), trata-se de uma espécie que pode ser recomendada para a formação de palhada em sistema de produção sob plantio direto, desde que implantada em solo com média a alta fertilidade. Apesar disso, não se encontram na bibliografia nacional, trabalhos científicos relacionados ao estudo agrobotânico desta espécie, sendo possível obter estas informações somente na bibliografia internacional.

Segundo Prasada Rao et al. (1994), as subespécies coracana incluem todos os cultivares de capim-pé-de-galinha cultivados, e as principais características agrobotânicas destas subespécies são: ser caracterizada como planta anual, entouceirada, ereta, ou com colmos ascendentes geniculados que podem alcançar até 1,65 m de altura, e algumas raízes saindo dos nós inferiores. Os colmos são comumente ramificados nos nós superiores para produzir inflorescências secundárias. As lâminas foliares são de lineares a lineares lanceoladas, medindo até $70 \mathrm{~cm}$ de comprimento e $20 \mathrm{~mm}$ de largura. As inflorescências são digitadas, freqüentemente com um ou mais rácemos logo abaixo do cacho principal, possuindo de 4 a 19 ramificações. As ramificações das inflorescências são finas, ou encurvadas na ponta quando robustas, algumas vezes com ramificações secundárias. A forma da inflorescência é variável. As espiguetas possuem de 6 a 9 flores e comprimento variando de 6 a $10 \mathrm{~mm}$, sobrepostas e na maioria das vezes arranjadas em duas longas fileiras ao longo de um dos lados da ráquis. As glumas são desiguais e mais curtas do que a espigueta. Os grãos podem ser branco, vermelho, castanho ou preto, mais ou menos globosos, possuindo até $2 \mathrm{~mm}$ de diâmetro, com a superfície finamente estriada. O arranjo das ramificações é de forma digitada e pode se 
espalhar e se tornar reflexiva, ou pode ser ereta e encurvada, freqüentemente formando uma estrutura em forma de punho.

O Eleusine coracana é predominantemente auto polinizável. As subespécies africana, contudo, se cruzam ocasionalmente com subespécies coracana produzindo híbridos totalmente férteis. Os resultados desses cruzamentos são agressivos e colonizadores, e formam raças espontâneas. O banco de germoplasma de Eleusine coracana montado pela Unidade de Recursos Genéticos do International Crops Research Institute for the Semi-Arid Tropics (ICRISAT) foi semeado em campos de alfissolos do Centro ICRISAT localizado em Patancheru na Índia e estudado morfologicamente. Quatorze características quantitativas e doze qualitativas foram registradas para cada acesso. Os dados foram derivados de observações em pelo menos 10 plantas em cada acesso. As principais características das diferentes raças são descritas a seguir (Prasada Rao et al., 1994):

- Raça elongata: esta raça é morfologicamente a mais distinta das cinco raças do capim-pé-de-galinha. Ela é caracterizada por inflorescências ramificadas que são longas e finas alcançando de 10 a $24 \mathrm{~cm}$ de comprimento, em forma digitada, se espalhando e curvando conforme se aproxima da maturidade. A sub-raça laxa tem os dedos longos e abertos com as espiguetas arranjadas em estreitas fileiras sobre as inflorescências ramificadas, assemelhando-se muito com a espécie selvagem africana. A sub-raça reclusa tem dedos curtos e abertos sem encurvamento das ramificações dos mesmos. A sub-raça sparsa tem também dedos abertos, porém as espiguetas são arranjadas em forma de cachos nas ramificações das inflorescências com espaços nus entre as mesmas.

- Raça plana: esta raça é caracterizada por longas espiguetas (8 a 15 mm de comprimento) que são arranjadas em mais ou menos duas fileiras pares ao longo da ráquis, dando às ramificações das inflorescências uma aparência achatada. Na sub-raça seriata as espiguetas são arranjadas em forma de série, dando uma típica aparência achatada. Na sub-raça confundere, os floretes férteis são numerosos e quase envolvem a ráquis na maturidade, dando desta maneira uma aparência compacta para a panícula. A sub-raça grandigluma é caracterizada por longas glumas pontudas, que são muitas e mais longas que as espiguetas. 
- Raça compacta: os membros desta raça são comumente chamados como capimpé-de-galinha “cokscomb”, tanto na África como na Índia. As espiguetas são compostas de nove ou mais floretes, algumas vezes com a axis da inflorescência dividida na base, ascendendo e encurvada na ponta para formar uma grande inflorescência em forma de punho.

- Raça vulgaris: este é o capim-pé-de-galinha comum da África e Ásia. Quatro sub-raças são morfologicamente reconhecidas através da inflorescência. Membros destas sub-raças estão freqüentemente crescendo juntas na mesma plantação, mas alguns agricultores as mantém como diferentes raças. Na sub-raça liliaceae, as ramificações das inflorescências são encurvadas; na stellata torcidas; na incurvata estas são encurvadas, algumas vezes dando a aparência de um punho; e, na digitata os dedos são encurvados nas pontas.

Quanto à composição química e o valor nutritivo do capim-pé-de-galinha, existem muitos estudos a respeito nos países produtores, devido a sua grande participação na dieta humana dos povos. Em média, cada 100 gramas de grãos a 12\% de umidade, possui 7,7 g de proteína, 1,5 g de lipídio, 2,6 g de cinzas e 0,4 g de cálcio, além de 336 kcal.

Subba Rao et al. (1994), referenciam estudo realizado na Índia com 21 cultivares de Eleusine coracana L. onde foram determinados índices agronômicos e características morfológicas. Os autores destacam a variação de 450 a $6010 \mathrm{~kg} \mathrm{ha}^{-1}$ para a produtividade de grãos, peso de caule variando de 1,0 a 8,6 g por planta e altura da planta variando de 0,57 a $1,17 \mathrm{~m}$.

Rao et al. (1989) obtiveram rendimento de grãos em seu experimento com o capim-pé-de-galinha da ordem de 1.049 a $2.442 \mathrm{~kg} \mathrm{ha}^{-1}$, enquanto os de forragem variaram de 2.200 a $5.600 \mathrm{~kg} \mathrm{ha}^{-1}$ de matéria seca. Subba Rao et al. (1994) citam a obtenção de rendimento de forragem da ordem de 11.050 a $12.480 \mathrm{~kg} \mathrm{ha}^{-1}$, e rendimento de grãos da ordem de 6.280 a $7.080 \mathrm{~kg} \mathrm{ha}^{-1}$, em experimentação com oito cultivares. 


\subsection{Aspectos Nutricionais Minerais do Eleusine coracana (L.) Gaertn.}

Quanto à influência da adubação para o Eleusine coracana (L.) Gaertn., a literatura internacional, principalmente a indiana, é rica em informações e trabalhos científicos a respeito dos efeitos da fertilização sobre o rendimento e a qualidade mineral do capim-pé-de-galinha.

Subba Rao et al. (1994), em experimentação com 3 níveis de adubação NPK (00:00:00; 50:25:25; 100:50:50) em três cultivares, determinaram a influência desta sobre o capim-pé-de-galinha. A produção de biomassa por hectare aumentou com os níveis e aplicação de NPK, sendo a média do tratamento 00:00:00 de 5.190 kg ha"-1 do tratamento 50:25:25 de 9.220 $\mathrm{kg} \mathrm{ha}^{-1}$, enquanto a média do tratamento 100:50:50 de $10.730 \mathrm{~kg} \mathrm{ha}^{-1}$. A produção de grãos também aumentou, obtendo-se uma média de produtividade de $2.100 \mathrm{~kg} \mathrm{ha}^{-1}, 3.440 \mathrm{~kg} \mathrm{ha}^{-1}$ e $4.150 \mathrm{~kg} \mathrm{ha}^{-1}$, respectivamente para os tratamentos 00:00:00; 50:25:25 e 100:50:50.

Subba Rao \& Prabhu (1996), conduziram um experimento com 3 cultivares e 3 níveis de adubação NPK (00:00:00; 25:20:12,5; 50:40:25). O rendimento de biomassa sofreu influência significativa da adubação, aumentando de $8.600 \mathrm{~kg} \mathrm{ha}^{-1}$ para $11.600 \mathrm{~kg}$ $\mathrm{ha}^{-1}$, assim como a altura de planta de 46,3 para $57,7 \mathrm{~cm}$.

O nitrogênio é um dos elementos essenciais de maior demanda para a maioria das culturas, e para o Eleusine coracana (L.) Gaertn. muitos estudos mostram que a cultura responde muito bem a este elemento. Rao et al (1989) analisando a resposta de 3 cultivares de Eleusine coracana L. sob 4 níveis de adubação nitrogenada (0, 20, 40 e 60 $\mathrm{kg} \mathrm{N} \mathrm{ha}^{-1}$ ), verificaram resposta significativa sobre o rendimento de grãos, altura de planta, número de perfilhos por planta, peso de mil grãos e sobre a produção de biomassa do capim-pé-de-galinha. Linge Gowda et al. (1994) comentam que já foram realizados muitos estudos sobre o assunto, e que as pesquisas tem demonstrado que a resposta do nitrogênio para a produção de grãos foi da ordem de 32,25 kg grão por kg de nitrogênio para a dose de $40 \mathrm{~kg} \mathrm{~N} \mathrm{ha}^{-1}$ e 15,5 kg grão por kg de nitrogênio para a dose de $60 \mathrm{~kg} \mathrm{~N} \mathrm{ha}{ }^{-1}$. Os autores recomendam ainda que o nitrogênio deve ser aplicado em duas vezes, ou seja, $50 \%$ no momento da semeadura e $50 \%$ seis semanas após a semeadura. 
Quanto à época de aplicação do nitrogênio, Rao et al. (1991) observaram que, quando a dose da adubação nitrogenada era dividida em três subdoses, ao invés de duas, obtinha-se substancial aumento no rendimento de grãos, provavelmente, causado pelo incremento do peso de espigas e do peso de 1000 grãos. Esta resposta, segundo os autores, deveu-se ao fato de a terceira subdose coincidir com a época de formação de espigas, demonstrando assim, haver influência não só da quantidade da adubação nitrogenada, como da sua época de aplicação.

Para o fósforo, um dos nutrientes mais importantes para a nutrição mineral de plantas, pesquisas demonstraram que a resposta do Eleusine coracana tem sido moderada. Durante dois anos de experimentação, Pilane et al. (1997) verificaram que após a aplicação de doses crescentes de nitrogênio (25; 50; 75 e $100 \mathrm{~kg} \mathrm{ha}^{-1}$ ) e fósforo (12,5; 25; 37,5 e $\left.50 \mathrm{~kg} \mathrm{ha}^{-1}\right)$ na cultura do capim-pé-de-galinha, os caracteres produtivos, como peso de panícula, peso de grãos por panícula e o rendimento foram aumentados. Os mesmos verificaram ter havido aumento no primeiro ano para doses de até 50 e $25 \mathrm{~kg}$ $\mathrm{ha}^{-1}$ de $\mathrm{N}$ e $\mathrm{P}$, respectivamente, provavelmente devido à inadequada quantidade de chuvas. Já no segundo ano, houve resposta para doses de $100 \mathrm{~kg} \mathrm{ha}^{-1}$ de $\mathrm{N}$ e $50 \mathrm{~kg} \mathrm{ha}^{-1}$ de $P$.

Segundo Mnyenyembe (1994), a adição do nitrogênio e do fósforo na cultura do capim-pé-de-galinha, aumenta significativamente a produtividade de grãos. O autor comenta que a dose ideal de nitrogênio e fósforo a ser aplicada no capim-pé-de-galinha é de 40 a $60 \mathrm{~kg} \mathrm{~N} \mathrm{ha}^{-1}$ e de 30 a $50 \mathrm{~kg} \mathrm{P}_{2} \mathrm{O}_{5} \mathrm{ha}^{-1}$. Para Linge Gowda et al. (1994), a resposta do capim-pé-de-galinha para a aplicação de fósforo tem sido moderada, obtendo-se resultados de 16,3 kg e 14,7 kg por $\mathrm{kg}$ de $\mathrm{P}_{2} \mathrm{O}_{5}$, com doses aplicadas de 30 e $60 \mathrm{~kg} \mathrm{ha}^{-1}$, respectivamente.

Já para o potássio, Linge Gowda et al. (1994), afirmam que a resposta do capimpé-de-galinha para a aplicação do nutriente foi mais baixa e alcançou entre 6 e 9 kg de grãos por kg de $\mathrm{K}_{2} \mathrm{O}$ na dose de 60 kg ha ${ }^{-1}$. Segundo Mnyenyembe (1994), o capim-péde-galinha não respondeu a aplicação de potássio, sendo esta ausência de resposta devida, provavelmente, ao fato de a maioria dos solos do Malawi não serem deficientes 
em potássio. Para Sherchan e Baniya (1994), a resposta do capim-pé-de-galinha para a aplicação de potássio tem sido negativa.

Mathan (1995) estudou a absorção de magnésio pelo capim pé-de-galinha em relação aos íons cálcio e potássio, trabalhando em áreas com e sem calagem, onde aplicou duas doses de potássio (0 e $100 \mathrm{~kg} \mathrm{ha}^{-1}$ ), e quatro de magnésio (0, 50, 100 e 150 $\left.\mathrm{kg} \mathrm{ha}{ }^{-1}\right)$. O autor observou que o rendimento de grãos e matéria seca aumentou significativamente com a aplicação de até $50 \mathrm{~kg} \mathrm{ha}^{-1}$ de $\mathrm{Mg}^{2+}$, e que acima deste valor houve redução. Quando o $\mathrm{Mg}^{2+}$ foi aplicado em doses crescentes, associadas a nenhuma aplicação de $\mathrm{K}^{+}$, o autor obteve um maior rendimento de grãos, ocorrendo redução neste parâmetro quando acrescentada a dose de $100 \mathrm{~kg} \mathrm{ha}^{-1}$ de $\mathrm{K}_{2} \mathrm{O}$ às doses crescentes de $\mathrm{Mg}^{+}$. Com relação ao calcário, quando o mesmo foi adicionado junto à dose zero de $\mathrm{Mg}^{2+}$, houve acréscimo significativo na produção de matéria seca total da planta, enquanto essa resposta tornou-se ausente quando doses elevadas de magnésio (100 e 150 $\mathrm{kg} \mathrm{ha}^{-1}$ ) foram aplicadas.

\subsection{Aspectos Nutricionais Minerais da Soja}

As plantas vivas são constituídas principalmente de água, que pode atingir até 95\% de seu peso, dependendo da espécie, idade e disponibilidade de água no meio. Segundo Malavolta (1985), aproximadamente 90\% da matéria seca da planta é constituída dos seguintes elementos químicos: carbono $(\mathrm{C})$, hidrogênio $(\mathrm{H})$ e oxigênio (O). A fonte inesgotável de carbono e oxigênio é o ar atmosférico. O hidrogênio tem como fonte a água, presente na litosfera, e que é absorvida via sistema radicular. Ao contrário do ar, a disponibilidade de água é limitante, podendo ocorrer déficits que restringem o crescimento das plantas.

Segundo Tanaka et al. (1993), qualquer elemento químico na natureza que esteja presente na solução do solo pode ser absorvido pela planta, sendo que somente 13 elementos inorgânicos são considerados essenciais à sua plena atividade, quais sejam: nitrogênio $(\mathrm{N})$, fósforo $(\mathrm{P})$, potássio $(\mathrm{K})$, cálcio $(\mathrm{Ca})$, magnésio $(\mathrm{Mg})$, enxofre $(\mathrm{S})$, boro (B), cloro (Cl), cobre (Cu), ferro (Fe), manganês (Mn), molibdênio (Mo) e zinco ( $\mathrm{Zn})$. 
Outros podem ser essenciais a espécies vegetais em processos específicos, dependendo ainda de uma comprovação através da pesquisa. Como exemplo, pode ser citado o caso do cobalto nas leguminosas, em que participa do processo simbiótico da fixação biológica do nitrogênio.

Segundo Bataglia et al. (1977), o acúmulo de matéria seca da parte aérea da soja aumenta em pequenas taxas até o início de florescimento, e a partir daí torna-se bastante elevada até a fase do início de formação de vagens. A partir do estádio de florescimento até cerca de 90 dias após emergência, onde o período vegetativo atinge o máximo, a translocação de nutrientes ocorre para as vagens e sementes, ocorrendo também, queda natural das folhas, iniciando-se a perda do peso total. Observa-se, que mais da metade da matéria seca acumulada pela cultura da soja é produzida depois do florescimento, o que leva a considerar este período como crítico. Em trabalho de pesquisa realizado por Francisco (2002), o autor afirma que a matéria seca total (MS) da planta de soja mostrou valores crescentes ao longo de todo o ciclo da cultura, atingindo o ponto de maior acúmulo no estádio $\mathrm{R}_{6}$, com $9.350 \mathrm{~kg}$ de $\mathrm{MS} \mathrm{ha}^{-1}$, mantendo-se estável até o estádio $\mathrm{R}_{7.2 \text {. }}$ Afirma ainda o autor, que a maior taxa de crescimento diário foi verificada entre os estádios $\mathrm{R}_{3}$ e $\mathrm{R}_{5.3}$, com 156,4 kg de MS ha-1 $\mathrm{dia}^{-1}$.

Segundo Vitti e Luz (1998), uma produtividade de grãos de soja correspondente a $3.000 \mathrm{~kg} \mathrm{ha}^{-1}$ exporta as seguintes quantidades $\left(\mathrm{kg} \mathrm{ha}^{-1}\right)$ de nutrientes minerais: 226 de N, 16 de P, 94 de K, 64 de Ca, 32 de Mg e 8 de S. Consideram também, que para esse nível de produtividade agrícola a lavoura de soja extrai as seguintes quantidades de nutrientes ( $\mathrm{kg} \mathrm{ha}^{-1}$ ): 300 de N, 40 de P, 115 de K, 70 de Ca, 35 de Mg e 23 de S. Excluindo o nitrogênio, que pode ser fornecido pela fixação biológica, nota-se que o potássio é o segundo elemento mais extraído pela planta, acompanhado pelo cálcio, magnésio, fósforo e enxofre. Devido ao fato do cálcio e o magnésio serem fornecidos principalmente pela calagem, resta atenção especial ao fósforo e ao potássio, macronutrientes diretamente envolvidos nas adubações de base da cultura. 


\subsubsection{Fósforo}

O fósforo é um macronutriente importante e necessário para o crescimento e o desenvolvimento das plantas. Está associado a muitas funções metabólicas vitais como: utilização de açúcares e amidos, fotossíntese, formação de núcleo e divisão de células e formação de gorduras e do endosperma, devendo estar presente em todas as células vivas. O fósforo é abundante no tecido meristemático de plantas jovens, sendo facilmente redistribuído dentro delas, podendo mover-se dos tecidos velhos para os novos, onde ocorre uma maior exigência fisiológica. Na maturidade das plantas, a maior quantidade do fósforo transloca-se para as sementes. No caso da soja, a quantidade percentual de fósforo transferida para as sementes é cerca de 87\% (Mascarenhas et al. 1993).

A importância do fósforo está relacionada a sua função nas plantas como constituinte de compostos armazenadores de alta energia, como o trifosfato de adenosina (ATP). É utilizando dessa energia que a semente germina, a planta efetua fotossíntese, nutre as bactérias fixadoras do $\mathrm{N}_{2}$, absorve de forma ativa os nutrientes do solo e sintetiza vários compostos orgânicos (Oliveira, 1996; Câmara, 2000). Outros compostos que contém fósforo são os derivados de inositol (fitinas), fosfolipídios e outros ésteres. As plantas absorvem o fósforo preferencialmente como ânion $\mathrm{H}_{2} \mathrm{PO}_{4}{ }^{-}$e em menor taxa como $\mathrm{HPO}_{4}{ }^{2-}$. Os primeiros compostos orgânicos formados com o fósforo dentro da planta são as fosfohexases e o difosfato de iridina, que são os precursores do ATP (Malavolta, 1980).

Nos solos das regiões tropicais e subtropicais, a maior parte do fósforo encontrase em formas pouco disponíveis às plantas, fator que, freqüentemente, tem limitado as produções agrícolas, fazendo com que as culturas nessas regiões sejam, praticamente, dependentes de adições de fertilizantes fosfatados.

Ao contrário do nitrogênio nas suas formas minerais, que apresentam grande mobilidade no solo, o que faz com que suas perdas no sistema sejam grandes, a mobilidade do fósforo é mínima e conseqüentemente, suas perdas por lixiviação são desprezíveis. Esse comportamento causa um grande acúmulo de $\mathrm{P}$ no solo ao longo de 
alguns anos de cultivo, como conseqüência residual ou do que sobra do aplicado no ano anterior e não utilizado pela planta. O fósforo apresenta reações típicas de adsorção com minerais da fração argila e precipitação com íons na solução do solo, que levam à sua imobilidade e, conseqüentemente, ao seu característico efeito residual. A fixação é hoje um termo genérico que engloba adsorção e precipitação (Novais \& Kamprath, 1978).

A quantidade de fósforo disponível na solução do solo, em um dado período, depende do balanço entre as adições e perdas. Como praticamente não se tem o fósforo na forma gasosa, este não apresenta perdas ou adições através da atmosfera. Considerase também, que a fixação seja um processo reversível, pois, com o passar do tempo, dependendo das condições do solo, parte dos fosfatos fixados podem tornar-se disponíveis (Lopes, 1989).

Quando a relação C/P no resíduo orgânico for menor que 200:1, ocorre a mineralização da matéria orgânica e a imobilização nos estágios iniciais da decomposição, quando a relação for maior que 300:1 (Follet et al., 1981).

Mascarenhas (1973) obteve resultados na fase de pré-floração da soja, isto é, até os 40 dias, em que a concentração de fósforo nas folhas e hastes foi de 0,39 e 0,17\%, respectivamente. Aos 60 dias, o autor encontrou as concentrações de 0,31 e 0,17\%, respectivamente. Já na fase de granação, correspondente ao período entre 100 e 140 dias, houve um decréscimo constante, tanto nas folhas como nas hastes, havendo um aumento de concentração nas vagens e sementes.

Mascarenhas et al. (1981), cita que após conduzir vários experimentos no ano agrícola 1973/1974, na região Norte e Nordeste do Estado de São Paulo, sob Latossolo Roxo distrófico e Latossolo Roxo eutrófico anteriormente cobertos por vegetação de cerrado, onde foi semeada a soja após a cultura de milho, algodão, soja, e também em experimentos similares conduzidos em 1979/80, no vale do Paranapanema, sob Latossolo Roxo eutrófico, onde também foi semeada a soja após trigo, não foram obtidas respostas à adubação fosfatada e potássica. Assim, os mesmos recomendam que não há necessidade de adubação da soja com fósforo e potássio, quando semeada em rotação após uma cultura adequadamente adubada, diminuindo assim, sensivelmente, o custo de produção. 
Pelos dados de Raij e Mascarenhas (1975), não há aumento de produção de soja devido à adubação fosfatada, quando a análise química do solo acusa $22 \mathrm{mg} \mathrm{dm}^{-3}$ ou mais de fósforo.

Cordeiro (1977) mostrou que a extração de $\mathrm{P}$ medida pelo seu acúmulo nas folhas da soja é relativamente lenta, até 52 dias após a emergência, onde está o ponto de inflexão da curva de absorção. Até então, as plantas tinham extraído 51,6\% do total. O ponto máximo de acúmulo deu-se aos 82 dias. Esta curva é semelhante à de acúmulo da matéria seca: absorção lenta no início, aumentando rapidamente até o início do enchimento dos grãos.

\subsubsection{Potássio}

O potássio está relacionado ao metabolismo e formação de carboidratos, a quebra e translocação do amido, atuando sobre o metabolismo do nitrogênio e a síntese de proteína, controle e regulagem da atividade de vários nutrientes, ativador de enzimas, promotor do crescimento de tecidos meristemáticos e ajuste da relação entre o movimento estomatal e a água (Malavolta, 1980).

Segundo Mascarenhas (1973), o potássio apresenta concentração elevada na soja, colocando-se em segundo lugar entre os macronutrientes extraídos pela cultura. Tanaka et al. (1993) confirmou estes dados, pois para uma produção média de 18 t de matéria seca da parte aérea por hectare, a cultura extraiu $343 \mathrm{~kg}$ e exportou 58 kg de potássio pelos grãos. Isto implica a necessidade de se usar doses mais elevadas do que aquelas recomendadas nas diversas regiões produtoras do Brasil, onde são obtidas altas produtividades, através de novos cultivares de maior potencial genético. Essa observação é procedente quando se sabe que o potássio aplicado ou nativo, além de exportado pelos grãos, é perdido por lixiviação e erosão.

Pesquisa realizada por Mascarenhas (1973), revela que no pré-florescimento, a concentração de potássio nas hastes e nas folhas foi de 2,90 e 2,16\% respectivamente, enquanto que no florescimento foi de 2,58 e 1,83\%, e no início da formação de vagens foi de 2,18 e 1,68\%. 
O potássio é absorvido pela planta a partir da solução do solo ou diretamente do complexo coloidal. A absorção somente ocorre após o contato com a superfície da raiz, o qual pode ser estabelecido de três modos: interceptação radicular, fluxo de massa ou, principalmente, por difusão (Malavolta, 1976).

De acordo com Schoroeder (1974) ${ }^{1}$ e Cooke $(1967)^{2}$, citados por Malavolta (1976), o fornecimento de potássio do solo para a planta pode ser descrito por três parâmetros: quantidade, intensidade e mobilidade. O parâmetro quantidade consiste no conteúdo do elemento presente no solo em forma disponível, ou seja, K trocável e parte do não trocável ou fixo. Já a intensidade consiste na atividade ou concentração de K na solução do solo. O parâmetro mobilidade pode ser definido como a velocidade com que uma certa quantidade de K é transportada para a zona radicular.

Segundo Rosolem (1997), plantas como a soja, podem absorver potássio considerado como não trocável no solo. O autor afirma que dependendo das características do solo, quando o teor de $\mathrm{K}$ trocável é menor que 1,2 a 1,4 $\mathrm{mmol}_{\mathrm{C}} \mathrm{dm}^{-3}$, a planta depende do $\mathrm{K}$ não trocável para sua nutrição, podendo haver prejuízo na produtividade.

Mascarenhas et al. (1971), obtiveram respostas esporádicas mediante a aplicação de potássio à soja. Entretanto os teores desse elemento, no solo, encontravam-se abaixo do nível crítico $\left(1,2 \mathrm{mmol}_{\mathrm{c}} \mathrm{dm}^{-3}\right)$. Apesar dos baixos teores de potássio trocável, não houve resposta da produção pela aplicação de doses crescentes de potássio.

\footnotetext{
${ }^{1}$ SCHROEDER, D. Relationships between soil potassium and the potassium nutrition of the plant. In: Potassium Research and Agricultural Production. $10^{\circ}$. Congr. do Instituto Internacional de Potassa, Budapest, 1974.

${ }^{2}$ COOKE, G. W. The control of soil fertility. Crosby Lockwood \& Son Ltd., Londres, 1967.
} 
Pesek (1968) ${ }^{3}$, citado por Mascarenhas et al. (1977), para explicar a ausência de resposta da soja à adubação potássica sugeriu que as plantas, após aproveitarem o potássio disponível do solo, são capazes de explorar as reservas de potássio não solúvel. Braga et al. (1976) ${ }^{4}$ citado por Mascarenhas et al. (1977), no Triângulo Mineiro, Minas Gerais, não obtiveram respostas na produção de soja perante a aplicação de potássio, em solos com baixo teor desse nutriente. A explicação dada foi que o extrator "North Carolina” retira do solo apenas o potássio disponível, mas não determina o potássio que poderia ser liberado durante o ciclo da cultura.

De acordo com Mascarenhas et al. (1975), quando a soja foi cultivada em rotação com milho, algodão e soja, adequadamente adubados nos seus respectivos plantios, não houve diferença na sua produção, recebendo ou não adubação por ocasião do seu plantio, concluindo, assim, que não há necessidade de adubação da soja quando semeada em rotação após uma cultura adequadamente adubada, diminuindo sensivelmente, o custo de produção.

Segundo Mascarenhas et al. (1988), em áreas deficientes em potássio é muito comum observar plantas sem vagens no terço superior, vagens vazias e retorcidas (sem desenvolvimento de sementes), senescência anormal (haste verde) e retenção foliar, chochamento e mal pegamento de vagens nos rácemos superiores. O autor cita que as observações referentes à adubação de soja, têm demonstrado que as melhores relações $(\mathrm{Ca}+\mathrm{Mg}) / \mathrm{K}$ estão entre os valores 22 e 31, independente do tipo de solo e do cultivar de soja, e que o potássio é muito importante para a cultura da soja, pois ajuda na formação de nódulos, reduz a deiscência das vagens, aumenta o teor de óleo nas sementes e também beneficia sua germinação, vigor e qualidade, além de aumentar sua resistência ao fungo Diaporthe phaseolorum sojae, causador da doença cancro da haste.

\footnotetext{
${ }^{3}$ PESEK, J. Potassium nutrition of soybeans and corn. In: KILMER, V. J.;YOUNTS, S. E.; BRADY, N. C. Eds. The role of potassium in agriculture. Madison, Wis. American Soc. Agron., 1968, p. 447 468.

${ }^{4}$ BRAGA, J. M.; FERRARI, R. A. R.; SEDIYAMA, C.; OLIVEIRA, L. M. Respostas do cultivar de soja Santa Rosa à aplicação de PK e calcário em Latossolos do Triângulo Mineiro. II - Correlação com análise química do solo. Anais do XV Congresso Brasileiro de Ciência do Solo. 1976. p. 289 293.
} 


\subsection{Adubação Antecipada de P e K em Agroecossistemas}

No Brasil, poucos pesquisadores têm pesquisado a antecipação da adubação da soja para uma cultura anterior. Em trabalho de pesquisa realizado por Francisco (2002), quanto ao acúmulo de matéria seca na soja, o mesmo verificou que os tratamentos que não obtiveram sua adubação antecipada, recebendo maior quantidade de P e K no sulco de semeadura, não demonstraram melhor nutrição das plantas, o que poderia resultar em plantas com maior acúmulo de matéria seca, se comparadas com plantas submetidas aos tratamentos cuja adubação foi antecipada para o capim pé-de-galinha. Como resultado, todos os tratamentos apresentaram a mesma curva de acúmulo de MS, o que também demonstra que a antecipação não promoveu prejuízo às plantas de soja.

Esteves (2000), através de experimento realizado em um solo classificado como NITOSSOLO VERMELHO distrófico, localizado na Fazenda Experimental Lageado, cidade de Botucatu/SP, estudou os efeitos da antecipação da adubação com fósforo e potássio recomendada para a soja, adicionando tal adubação nas culturas de inverno (aveia preta e milheto). O cultivar de soja utilizado foi o IAC-17 semeado sob o sistema de semeadura direta. O autor verificou ao término dos trabalhos que: com temperaturas médias mínimas de $15^{\circ} \mathrm{C}$ e máximas de $23^{\circ} \mathrm{C}$, a aveia preta se desenvolveu mais que o milheto, acumulando mais P e K; a degradação da palha da aveia preta foi mais rápida do que a do milheto; após o dessecamento, o $\mathrm{K}$ acumulado nos adubos verdes foi liberado em mais de $90 \%$ no solo em um período de 60 dias; utilizando a adubação fosfatada no cultivo de espécies durante o inverno, aumentou a disponibilidade de P para a cultura seguinte e que a soja acumulou maior quantidade de P e K; a produtividade da soja foi influenciada tanto pela adubação PK como pelas espécies de adubos verdes, e, que a adubação PK realizada na semeadura da soja proporcionou maior produtividade comparada à adubação PK na semeadura dos adubos verdes, apresentando um rendimento cerca de 65\% mais elevado; a adubação PK realizada na semeadura da soja, proporcionou uma maior massa de 100 grãos com relação à aplicação da mesma na semeadura dos adubos verdes, tanto sob aveia preta como milheto. 
Lantmann e Castro (2004), analisando os rendimentos de grãos de milho (safra 96/97), soja (safra 97/98), trigo (safra 98) e soja (safra 98/99), cultivados em sucessão após oito anos de fertilizantes aplicados para a sucessão soja/trigo, e respectiva concentração de $\mathrm{P}$ e $\mathrm{K}$ no solo, em Latossolo Roxo distrófico, observaram que os melhores rendimentos da soja (3.147 $\mathrm{kg} \mathrm{ha}^{-1}$ e $3.539 \mathrm{~kg} \mathrm{ha}^{-1}$ ) foram encontrados onde as concentrações de fósforo $\left(9,3 \mathrm{mg} \mathrm{dm}^{-3}\right)$ e de potássio $\left(2,0 \mathrm{mmol}_{\mathrm{c}} \mathrm{dm}^{-3}\right)$ no solo não foram as mais altas, o que não ocorreu com o milho e o trigo, pois os melhores rendimentos ocorreram com as maiores concentrações de fósforo (17,8 $\left.\mathrm{mg} \mathrm{dm}^{-3}\right)$ e de potássio $\left(4,4 \mathrm{mmol}_{\mathrm{C}} \mathrm{dm}^{-3}\right)$. Os autores verificaram também que na safra 98/99, a soja com produção de $3.539 \mathrm{~kg} \mathrm{ha}^{-1}$ foi obtida no tratamento que não recebeu adubação fosfatada ou potássica, diferentemente do observado para as culturas de milho e trigo, em que, os melhores rendimentos ocorreram quando ambos foram adubados. 


\section{MATERIAL E MÉTODOS}

\subsection{Local e Época da Realização do Experimento}

A pesquisa foi realizada na Estação Experimental Anhembi, área sob a coordenação do Departamento de Genética, pertencente à Escola Superior de Agricultura “Luiz de Queiroz” (USP/ESALQ), no município de Piracicaba-SP, localizada à margem direita do Rio Tietê, na cabeceira da represa de Barra Bonita-SP, entre as coordenadas $22^{\circ} 45^{\prime}$ e $22^{\circ} 50^{\prime}$ de latitude Sul, e $48^{\circ} 00^{\prime}$ e $45^{\circ} 05^{\prime}$ de longitude Oeste e 530 m de altitude média.

A área possui um histórico de vinte anos de pastagem seguidos de dois anos com cultivo de milho, onde antes da implantação do milho foi efetuada a correção da acidez do solo com calcário dolomítico.

O experimento foi conduzido em sistema de semeadura direta da soja sobre a palhada de Eleusine coracana (L.) Gaertn. (capim-pé-de-galinha), instalado em condições de campo, durante o ano agrícola 2001/2002. A instalação do experimento ocorreu em 06 de setembro de 2001, com a semeadura do capim-pé-de-galinha, com a finalidade de obtenção de cobertura morta. A semeadura da soja foi realizada em 06 de dezembro de 2001. Já a colheita da soja foi efetuada em 12 de abril de 2002.

\subsection{Características e Manejo do Solo}

O solo da área experimental é classificado como LATOSSOLO AMARELO Distrófico, contendo $200 \mathrm{~g} \mathrm{~kg}^{-1}$ de argila, $80 \mathrm{~g} \mathrm{~kg}^{-1}$ de silte e $720 \mathrm{~g} \mathrm{~kg}^{-1}$ de areia. As características químicas desse solo foram determinadas no Laboratório de Análises 
Químicas de Solo do Departamento de Solos e Nutrição de Plantas da USP/ESALQ a partir da amostragem do mesmo (Tabelas 1 e 2).

Tabela 1. Composição química do solo da área experimental, nas profundidades de 0-20, 20-40 e 40-60 cm

\begin{tabular}{|c|c|c|c|c|c|c|c|c|c|c|c|c|c|}
\hline \multirow{2}{*}{$\begin{array}{c}\text { Prof. }{ }^{1} \\
\text { cm }\end{array}$} & \multirow{2}{*}{$\begin{array}{c}\mathrm{pH} \\
\mathrm{CaCl}_{2}\end{array}$} & \multirow{2}{*}{$\begin{array}{l}\text { M.O. } \\
\mathrm{g} \mathrm{dm}^{-3}\end{array}$} & $\mathrm{P}$ & S & $\mathrm{K}$ & $\mathrm{Ca}$ & $\mathrm{Mg}$ & $\mathrm{Al}$ & $\mathrm{H}+\mathrm{Al}$ & SB & $\mathrm{T}$ & $\mathrm{V}$ & $\mathrm{m}$ \\
\hline & & & & $m^{-3}$ & \multicolumn{7}{|c|}{$\mathrm{mmol}_{\mathrm{c}} \mathrm{dm}^{-3}$} & \multicolumn{2}{|c|}{$\%$} \\
\hline $0-20$ & 6,4 & 31 & 6 & 19 & 1,9 & 22 & 15 & 1 & 22 & 38,9 & 60,9 & 64 & 3 \\
\hline $20-40$ & 3,9 & 21 & 4 & 32 & 1,2 & 9 & 6 & 12 & 47 & 16,2 & 63,2 & 26 & 43 \\
\hline $40-60$ & 4,5 & 16 & 3 & 35 & 0,9 & 6 & 3 & 16 & 42 & 9,9 & 51,9 & 19 & 62 \\
\hline
\end{tabular}

Tabela 2. Teores de micronutrientes do solo da área experimental, nas profundidades de 0-20, 20-40 e 40-60 cm

\begin{tabular}{cccccc}
\hline Prof. $^{1}$ & B & $\mathrm{Cu}$ & $\mathrm{Fe}$ & $\mathrm{Mn}$ & $\mathrm{Zn}$ \\
\hline $\mathrm{cm}$ & & & $\mathrm{mg} \mathrm{dm}^{-3}$ & & \\
$0-20$ & - & 0,8 & 88 & 4,4 & 0,9 \\
$20-40$ & - & 2,2 & 47 & 0,4 & 2,8 \\
$40-60$ & - & 1,1 & 35 & 0,6 & 1,1 \\
\hline
\end{tabular}

${ }^{1}$ Prof. = profundidade de amostragem.

Segundo os resultados da análise química do solo (Tabela 1), não foi necessário efetuar a calagem para a implantação do experimento. Para o pleno desenvolvimento e formação de palhada pela cultura do capim-pé-de-galinha, foi aplicado nitrogênio em área total na dose equivalente a $30 \mathrm{~kg} \mathrm{ha}^{-1}$. Na Tabela 2, o boro encontra-se tão baixo no solo que não foi detectado pela análise de solo.

A recomendação de adubação de base da cultura de soja, constituída de fósforo e potássio, foi fundamentada na fertilidade do solo, revelada pela análise química, e na produtividade do cultivar estimada para $3.000 \mathrm{~kg} \mathrm{ha}^{-1}$. O nitrogênio foi fornecido para a soja pelo sistema de fixação biológica, a partir da inoculação das sementes com 
inoculante turfoso. Durante o desenvolvimento da cultura, os micronutrientes foram fornecidos por meio de pulverização foliar, a fim de que as plantas de soja não fossem submetidas a nenhuma deficiência nutricional.

\subsection{Características dos Cultivares}

Com relação ao capim-pé-de-galinha, foi utilizado o cultivar “ANSB Pé-degalinha 5352” pertencente à espécie Eleusine coracana (L.) Gaertn.. Quanto à soja, foi utilizado o cultivar BRS-133, que tem apresentado excelentes níveis de produtividade nas regiões agrícolas do Estado de São Paulo, cujas principais características são apresentadas na Tabela 3.

Tabela 3. Características agronômicas do cultivar de soja BRS-133

\begin{tabular}{cc}
\hline Características & BRS-133 \\
\hline Procedência & EMBRAPA \\
Genealogia & Ft-Abyara x BR 83-147 \\
Ciclo (dias) & 120 a 130 \\
Ciclo (classificação) & Semi Precoce \\
Altura de planta (cm) & 82 \\
Habito de crescimento & Determinado \\
Cor da flor & Branca \\
Cor da Pubescência & Marrom \\
Cor do tegumento & Amarelo \\
Acamamento & Resistente \\
Época de semeadura recomendada & 15/Outubro a 15/Dezembro \\
Reação a doenças & Resistente \\
Cancro da haste & Resistente \\
Pústula bacteriana & Oídio \\
Mosaico comum & Moderadamente suscetível \\
Mancha olho-de-rã & Resistente \\
Crestamento bacteriano & Suscetível \\
Nematóides de galha &
\end{tabular}

Fonte: Embrapa (2000). 


\subsection{Delineamento e Unidade Experimental}

Adotou-se o delineamento experimental em blocos ao acaso com 12 tratamentos (níveis de manejo da adubação) e três repetições.

A parcela experimental foi constituída de duas áreas úteis: a) seis linhas de $12 \mathrm{~m}$ de comprimento por $3 \mathrm{~m}$ de largura $\left(36 \mathrm{~m}^{2}\right)$ para determinações de variáveis não destrutivas e, b) seis linhas de 10 metros de comprimento por 3 metros de largura (30 $\mathrm{m}^{2}$ ) para determinação de variáveis destrutivas. Portanto, a parcela experimental foi dimensionada para conter dezoito linhas de soja com $12 \mathrm{~m}$ de comprimento, espaçadas de $0,5 \mathrm{~m}$, totalizando uma área de $108 \mathrm{~m}^{2}$. O esquema da parcela experimental é demonstrado na Figura 1.

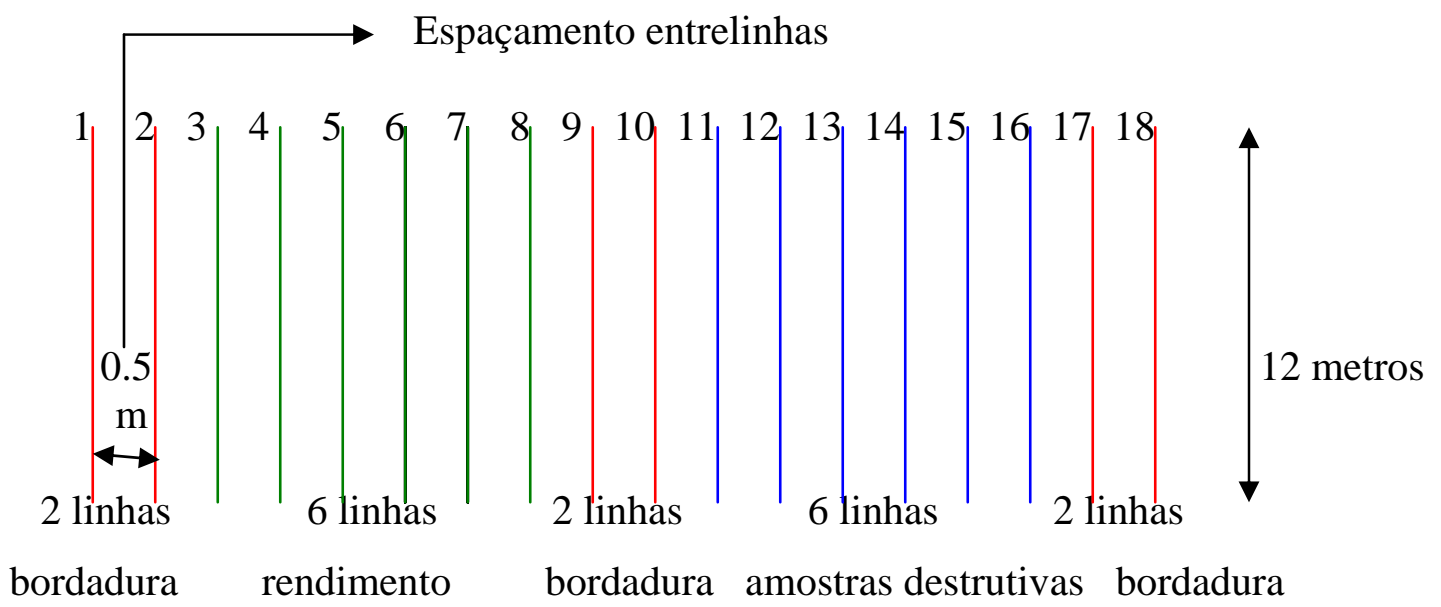

Figura 1 - Esquema da unidade experimental para a cultura da soja.

O experimento foi instalado de modo a antecipar a adubação de base da cultura da soja sendo colocada, parcial ou totalmente, na semeadura do capim-pé-de-galinha, de acordo com o esquema apresentado na Tabela 4. 
Tabela 4. Tratamentos experimentais aplicados às parcelas, correspondentes à adubação com fósforo (P) e potássio (K), em doses $\left(\mathrm{kg} \mathrm{ha}^{-1}\right)$ equivalentes a $\mathrm{P}_{2} \mathrm{O}_{5}$ e $\mathrm{K}_{2} \mathrm{O}$

\begin{tabular}{cccc}
\hline Tratamentos & $\begin{array}{c}\text { Capim } \\
\text { Pé-de-Galinha }\end{array}$ & Soja & Total \\
\hline T1 & $00 \mathrm{P}+00 \mathrm{~K}$ & $00 \mathrm{P}+00 \mathrm{~K}$ & $00 \mathrm{P}+00 \mathrm{~K}$ \\
$\mathrm{~T} 2$ & $00 \mathrm{P}+00 \mathrm{~K}$ & $90 \mathrm{P}+50 \mathrm{~K}^{1}$ & $90 \mathrm{P}+50 \mathrm{~K}^{1}$ \\
$\mathrm{~T} 3$ & $00 \mathrm{P}+25 \mathrm{~K}$ & $90 \mathrm{P}+25 \mathrm{~K}^{1}$ & $90 \mathrm{P}+50 \mathrm{~K}^{1}$ \\
T4 & $00 \mathrm{P}+50 \mathrm{~K}$ & $90 \mathrm{P}+00 \mathrm{~K}^{1}$ & $90 \mathrm{P}+50 \mathrm{~K}^{1}$ \\
T5 & $45 \mathrm{P}+00 \mathrm{~K}$ & $45 \mathrm{P}+50 \mathrm{~K}^{1}$ & $90 \mathrm{P}+50 \mathrm{~K}^{1}$ \\
T6 & $45 \mathrm{P}+25 \mathrm{~K}$ & $45 \mathrm{P}+25 \mathrm{~K}^{1}$ & $90 \mathrm{P}+50 \mathrm{~K}^{1}$ \\
T7 & $45 \mathrm{P}+50 \mathrm{~K}$ & $45 \mathrm{P}+00 \mathrm{~K}^{1}$ & $90 \mathrm{P}+50 \mathrm{~K}^{1}$ \\
T8 & $90 \mathrm{P}+00 \mathrm{~K}$ & $00 \mathrm{P}+50 \mathrm{~K}^{1}$ & $90 \mathrm{P}+50 \mathrm{~K}^{1}$ \\
T9 & $90 \mathrm{P}+25 \mathrm{~K}$ & $00 \mathrm{P}+25 \mathrm{~K}^{1}$ & $90 \mathrm{P}+50 \mathrm{~K}^{1}$ \\
T10 & $90 \mathrm{P}+50 \mathrm{~K}$ & $00 \mathrm{P}+00 \mathrm{~K}^{1}$ & $90 \mathrm{P}+50 \mathrm{~K}^{1}$ \\
T11 & $90 \mathrm{P}+50 \mathrm{~K}^{1}$ & $00 \mathrm{P}+00 \mathrm{~K}$ & $90 \mathrm{P}+50 \mathrm{~K}^{1}$ \\
T12 & $00 \mathrm{P}+00 \mathrm{~K}^{1}$ & $90 \mathrm{P}+50 \mathrm{~K}$ & $90 \mathrm{P}+50 \mathrm{~K}^{1}$ \\
\hline
\end{tabular}

${ }^{1}$ Adubação foliar com micronutrientes

Algumas observações são necessárias para a compreensão dos tratamentos apresentados na Tabela 4. A adubação total refere-se à adubação recomendada para a cultura da soja em sistema de alta tecnologia, segundo o Boletim Técnico $\mathrm{n}^{0} 100$ do Instituto Agronômico de Campinas-SP, levando-se em consideração a fertilidade do solo e a estimativa de produtividade do cultivar utilizado. A recomendação adotada consistiu da aplicação de $90 \mathrm{~kg} \mathrm{ha}^{-1}$ de $\mathrm{P}_{2} \mathrm{O}_{5}$, na forma de superfosfato triplo (45\% de $\mathrm{P}_{2} \mathrm{O}_{5}$ ) e 50 $\mathrm{kg} \mathrm{ha}^{-1}$ de $\mathrm{K}_{2} \mathrm{O}$, na forma de cloreto de potássio $\left(60 \%\right.$ de $\left.\mathrm{K}_{2} \mathrm{O}\right)$. Também foi realizada a aplicação via foliar dos micronutrientes cobalto e molibdênio, na dose de $150 \mathrm{~mL} \mathrm{ha}^{-1}$ do produto comercial (Co: 3,825 $\mathrm{g} \mathrm{ha}^{-1}$; Mo: 38,25 $\mathrm{g} \mathrm{ha}^{-1}$ ), além de boro, cobre, manganês e zinco, na dose de 4 litros ha ${ }^{-1}$ (sendo esta dose dividida em duas aplicações, aos 30 e 45 dias após emergência da cultura) do produto comercial (B: 25,2 g ha ${ }^{-1}$; Cu: 25,2 g ha-1. Mn: 151,2 $\mathrm{g} \mathrm{ha}^{-1}$; Zn: $252 \mathrm{~g} \mathrm{ha}^{-1}$ ). A adubação total recomendada não foi adicionada no tratamento controle (testemunha). 


\subsection{Preparo da Área, Instalação e Condução do Experimento}

O preparo inicial do solo foi realizado através do uso de uma grade aradora. Em seguida foi realizada uma gradagem leve utilizando-se de uma grade niveladora. Para tentar minimizar a possível interferência da elevada saturação por alumínio na profundidade de 20 a $40 \mathrm{~cm}$, aplicou-se o gesso agrícola na dose de $500 \mathrm{~kg} \mathrm{ha}^{-1}$, incorporando-o ao solo com o uso de grade niveladora.

Nas parcelas cujos tratamentos indicam a antecipação da adubação, esta foi realizada a lanço, de forma manual. Logo após a adubação, procedeu-se a semeadura do capim-pé-de-galinha (Figuras 2 e 3), também realizada a lanço, porém, com o uso do distribuidor pendular de sementes, utilizando-se uma quantidade de sementes de $12 \mathrm{~kg}$ $\mathrm{ha}^{-1}$. Para obter uma melhor uniformidade de distribuição das sementes na área, as sementes foram misturadas com areia grossa e seca na proporção de 0,5 kg de sementes por balde de 20 litros de areia, facilitando a regulagem do equipamento.

Para os tratamentos que envolveram a aplicação de micronutrientes no capim-péde-galinha, os mesmos foram aplicados em uma única aplicação, aos 45 dias após a emergência.

Antes da dessecação do capim-pé-de-galinha (Figuras 4 e 5), foi realizada uma coleta em 1,0 $\mathrm{m}^{2}$ de cada parcela para fins de determinação da produção de matéria seca, coleta esta realizada quando o capim encontrava-se no estádio de florescimento (Figuras 6 e 7). Em seguida, foi realizada a dessecação, utilizando-se o herbicida glifosato na dose de 2,4 kg de i.a. por hectare (5 litros do produto comercial ha ${ }^{-1}$ ), com um volume de calda equivalente a 300 litros ha ${ }^{-1}$ (Figuras 8 e 9).

A adubação da cultura da soja foi realizada manualmente, distribuindo-se o adubo dentro do sulco, previamente aberto pela máquina semeadora-adubadora de parcelas, operação esta efetuada antes da semeadura.

Antecedendo a semeadura direta da cultura da soja, as sementes foram tratadas com o fungicida carboxin + thiram na dosagem de $50 \mathrm{~g}$ de carboxin por $100 \mathrm{~kg}^{-1}$ de sementes e $50 \mathrm{~g}$ de thiram por $100 \mathrm{~kg}^{-1}$ de sementes (0,25 L p.c. $100 \mathrm{~kg}^{-1}$ de sementes), visando proteger o sistema semente-plântula contra a ação de fungos fitopatogênicos do 
solo. Em seguida foram inoculadas com inoculante turfoso, na dosagem de 0,30 $\mathrm{kg}$ do produto comercial por $100 \mathrm{~kg}$ de semente, correspondendo a 600.000 células de bradirrizóbios por semente.

A semeadura foi realizada utilizando-se semeadora-adubadora de parcelas de quatro linhas, com espaçamento entre linhas de $0,50 \mathrm{~m}$, de forma a se obter população

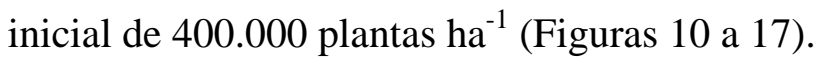

Os tratos culturais aplicados às parcelas foram os mesmos aplicados à cultura da soja em áreas de plantios comerciais, com o manejo químico das plantas daninhas e das pragas, conforme levantamento de campo realizado para estes elementos bióticos. No controle das plantas daninhas de folhas largas foi utilizado o herbicida imazaquin na dosagem de $70 \mathrm{~g} \mathrm{ha}^{-1}$ de i.a. (0,1 $\mathrm{kg} \mathrm{ha}^{-1}$ do p.c.) e flumetzulan na dosagem de $60 \mathrm{~g} \mathrm{ha}^{-1}$ de i.a. (0,5 L ha ${ }^{-1}$ do p.c.) em pré-emergência da cultura e das plantas daninhas (Figura 18). Para o controle das plantas daninhas de folhas estreitas foi utilizado o herbicida à base de clethodim na dosagem de $108 \mathrm{~g} \mathrm{ha}^{-1}$ de i.a. (0,45 L ha-1 do p.c.) em mistura com óleo mineral (0,50\% v/v), em pós-emergência das plantas daninhas e da cultura.

O monitoramento da população das principais pragas da soja (lagartas desfolhadoras e complexo de percevejos) foi efetuado pela técnica do "pano de batida”, adotando-se como critério para dano econômico, a presença de dois percevejos e 40 lagartas (maiores que 1,5 cm), em média, por ocasião das amostragens (Panizzi, 1990). Para o controle de pragas foi utilizado o Bacillus thuringiensis aos 39 dias após emergência da cultura na dosagem de $16 \times 10^{9}$ U.I. do i.a. (0,50 kg ha ${ }^{-1}$ do p.c.) para o controle da lagarta da soja (Anticarsia gemmatalis), e metamidofós na dosagem $360 \mathrm{~g}$ ha ${ }^{-1}$ do i.a. (0,60 L ha ${ }^{-1}$ do p.c.) aos 60 e 80 dias após emergência da cultura para o controle do percevejo marrom (Euschistus heros) e do percevejo verde pequeno (Piezodorus guildinii).

Para controlar as doenças de final de ciclo, entre os estádios fenológicos $R_{5.1}$ e $\mathrm{R}_{5.3}$ (Figura 19 e 20), utilizou-se o fungicida à base de carbendazim na dosagem de 250 g ha ${ }^{-1}$ do i.a. (0,5 $\mathrm{L} \mathrm{ha}^{-1}$ do p.c.). 


\subsection{Colheita do Experimento}

Identificado o ponto de colheita (Figura 21), foram coletadas 10 plantas de cada parcela para fins de determinações laboratoriais (componentes da produção).

A colheita foi realizada com colhedora automotriz de parcelas com regulagem da velocidade do cilindro batedor para 720 rotações por minuto (Figura 22).

\subsection{Parâmetro Avaliado no Capim-pé-de-galinha}

\subsubsection{Produção de matéria seca pelo capim-pé-de-galinha}

Dois dias antes da dessecação providenciou-se a coleta de uma amostra de 1,0 $\mathrm{m}^{2}$ de capim-pé-de-galinha por parcela, para determinação da massa de matéria seca. Cada amostra foi encaminhada para secagem artificial em estufa por 72 horas a $70^{\circ} \mathrm{C}$, pesada em seguida para determinação da massa de matéria seca. Posteriormente foi realizada a transformação dos dados de $\mathrm{kg}_{\text {parcela }}{ }^{-1}$ para $\mathrm{kg} \mathrm{ha}^{-1}$, calculando-se a produtividade de matéria seca do Eleusine coracana (L.) Gaertn..

\subsection{Parâmetros Avaliados na Soja}

\subsubsection{Estande final}

Para determinação do estande final de plantas foram realizadas seis amostragens de 1,0 $\mathrm{m}$ ao acaso por parcela.

\subsubsection{Altura final de planta}

Para determinação da altura final de planta foi medida a altura de 10 plantas ao acaso por parcela.

\subsubsection{Porcentagem de plantas com haste verde}

Em cada linha de colheita foi tomada uma amostragem ao acaso de 1,0 m, totalizando seis amostras por parcela. Para cada amostragem foram contadas as plantas 
totais e aquelas que apresentavam haste verde, calculando-se, posteriormente, a porcentagem de plantas com haste verde (Figuras 23 e 24).

\subsubsection{Grau de acamamento}

Avaliado por notas visuais seguindo-se a escala de 1 a 5 , descrita a seguir: $1=$ acamamento de plantas de 0 a $20 \%$; 2 = acamamento de plantas variando de 21 a $40 \%$; 3 = acamamento de plantas variando de 41 a $60 \%$; 4 = acamamento de plantas variando de 61 a 80 \%; 5 = acamamento de plantas variando de 81 a 100 \% (Figura 25).

\subsubsection{Número de ramificações por planta}

Determinado por meio da contagem direta de todas as ramificações existentes em cada planta.

\subsubsection{Número de vagens chochas por planta}

Obtido pela contagem do número de vagens chochas existentes em cada planta.

\subsubsection{Número de vagens de 3 cavidades com 3 grãos}

Avaliado pela contagem do número de vagens de 3 cavidades por planta contendo 3 grãos.

\subsubsection{Número de vagens de 3 cavidades com 2 grãos}

Determinado pela contagem do número de vagens de 3 cavidades por planta contendo 2 grãos.

\subsubsection{Número de vagens de 3 cavidades com 1 grão}

Obtido pela contagem do número de vagens de 3 cavidades por planta contendo 1 grão. 


\subsubsection{Número de vagens de 2 cavidades com 2 grãos}

Avaliado pela contagem do número de vagens de 2 cavidades por planta contendo 2 grãos.

\subsubsection{Número de vagens de 2 cavidades com 1 grão}

Determinado pela contagem do número de vagens de 2 cavidades por planta contendo 1 grão.

\subsubsection{Número de vagens de 1 cavidade com 1 grão}

Obtido pela contagem do número de vagens de 1 cavidade por planta contendo 1 grão.

\subsubsection{Número total de vagens por planta}

Calculado através do somatório de todas as vagens encontradas em cada planta, inclusive as vagens chochas.

\subsubsection{Número total de grãos por planta}

Determinado pela contagem do número total de grãos debulhados de cada planta.

\subsubsection{Peso de grãos por planta}

Os grãos debulhados em cada planta foram pesados efetuando-se, em seguida, a homogeneização dos grãos das 10 plantas por parcela em um único recipiente.

Para obter o peso final dos grãos, determinou-se a umidade destes em duas amostras por parcela, pelo método da estufa a $105^{\circ} \mathrm{C} \pm 3^{\circ} \mathrm{C}$, durante 24 horas, segundo as prescrições das Regras de Análises de Sementes - RAS (Brasil, 1992). Posteriormente esses valores foram corrigidos a 13\% de umidade, utilizando-se a fórmula descrita na expressão a seguir:

$$
\text { Mc = Mo [1- (Uo / 100)] / [1 - Uc / } 100)]
$$


onde:

$$
\begin{aligned}
& \text { Mc = massa corrigida; } \\
& \text { Mo = massa observada; } \\
& \text { Uo = grau de umidade observado em porcentagem; } \\
& \text { Uc = grau de umidade de correção em porcentagem. }
\end{aligned}
$$

\subsubsection{Produtividade agrícola}

Por ocasião da colheita e para efeito de bordadura desconsiderou-se 1,0 m em cada extremidade de linha útil, de maneira que a área colhida por parcela correspondeu a $30 \mathrm{~m}^{2}$. A massa de grãos de soja colhida por parcela foi encaminhada ao Laboratório de Análises de Sementes do Departamento de Produção Vegetal da USP/ESALQ, para beneficiamento, pesagem e determinação da umidade. Posteriormente, calculou-se a produtividade agrícola $\left(\mathrm{kg} \mathrm{ha}^{-1}\right)$ corrigida a $13 \%$ de umidade, conforme a expressão apresentada para peso de grãos por planta.

\subsubsection{Peso de 1000 grãos}

Para obtenção do peso de 1000 grãos foram separadas 8 sub-amostras de 100 grãos por parcela, cujos pesos foram determinados em balança com sensibilidade de centésimos de grama, sendo tais procedimentos efetuados segundo as prescrições estabelecidas pelas RAS (Brasil, 1992). Para chegar à massa de 1000 grãos, determinouse a umidade destes em duas amostras por parcela pelo método da estufa, a $105^{\circ} \mathrm{C} \pm 3^{\circ} \mathrm{C}$, durante 24 horas (Brasil, 1992), sendo os resultados expressos em porcentagem média por parcela. Posteriormente esses valores foram corrigidos para 13\%, utilizando-se a fórmula descrita para peso de grãos por planta e produtividade agrícola. 


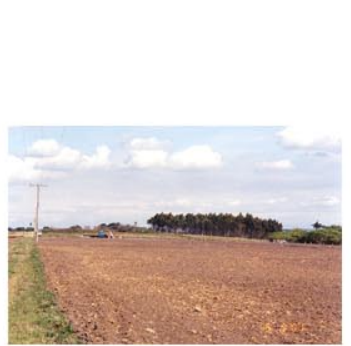

Figura 2 - Solo preparado para a semeadura do capim-pé-degalinha.

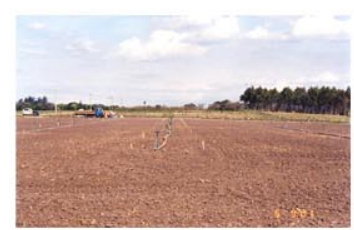

Figura 3 - Semeadura do capimpé-de-galinha, já realizada.

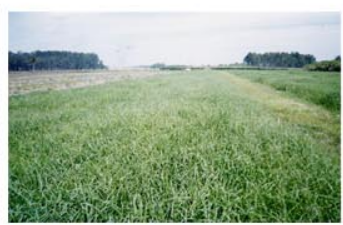

Figura 4 - Desenvolvimento do capim-pé-de-galinha.

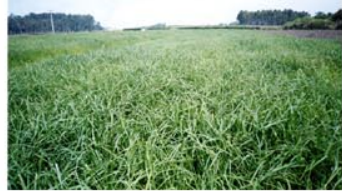

Figura 5 - Vista geral da área experimental: capim-pé-degalinha.

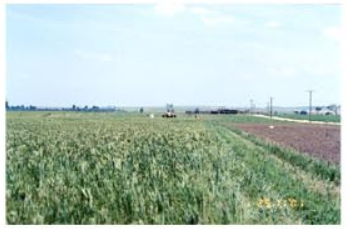

Figura 6 - Ponto de dessecação do capim-pé-de-galinha.
Figura 7 - Inflorescência do capim-pé-de-galinha.

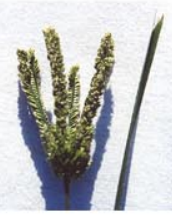

Figura 8 - Operação de dessecação do capim-pé-de-galinha.
Figura 9 - Capim-pé-de-galinha após 7 dias da dessecação.

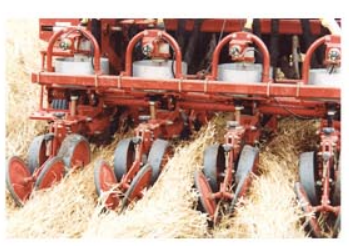

Figura 10 - Semeadura da soja.

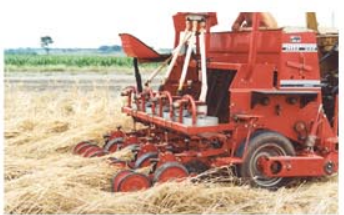

Figura 11 - Operação de semeadura da soja.

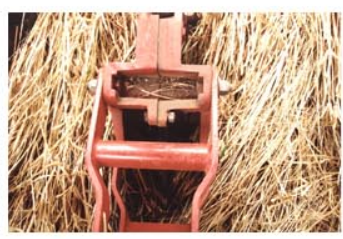

Figura 12 - Detalhe do mecanismo de semeadura de uma linha de soja.

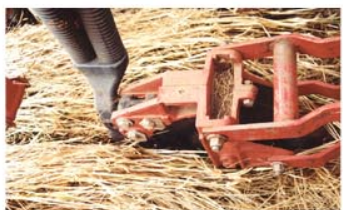

Figura 13 - Detalhe da lateral do mecanismo de semeadura de uma linha de soja. 


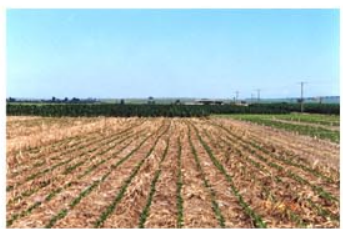

Figura 14 - Desenvolvimento inicial da soja.

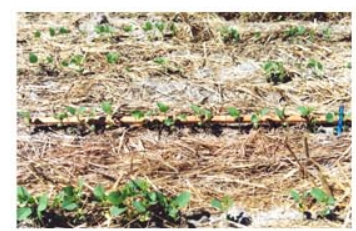

Figura 15 - Detalhe do estande inicial da soja.

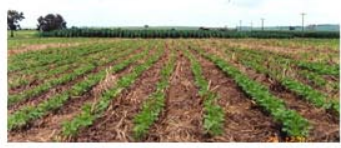

Figura 16 - Desenvolvimento vegetativo da soja.

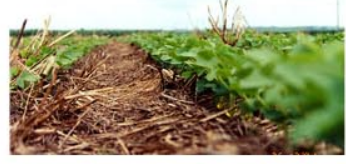

Figura 17 - Detalhe do desenvolvimento vegetativo da soja.

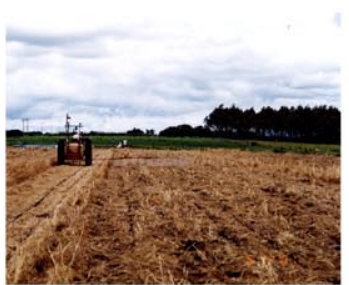

Figura 18 - Operação de aplicação de herbicida pré-emergente na soja.

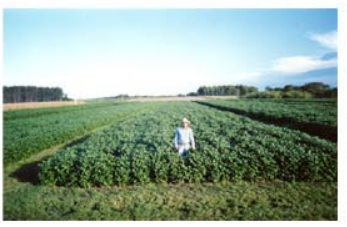

Figura 19 - Vista geral da área: soja em fase reprodutiva.

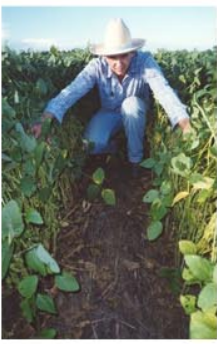

Figura 20 - Soja em fase reprodutiva com detalhe para os restos culturais do capim-pé-degalinha.

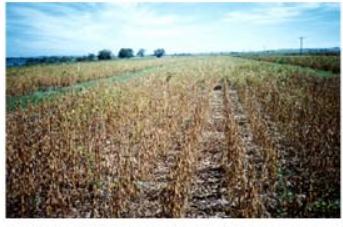

Figura 21 - Soja na fase de pré-colheita.

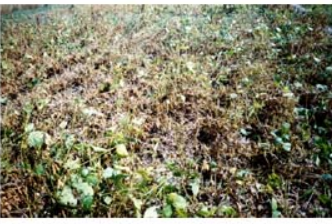

Figura 23 - Detalhe da presença de haste verde e retenção foliar.

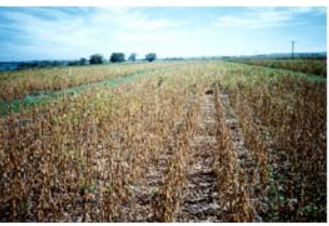

Figura 24 - Detalhe de parcela com tratamento controle, sem presença de plantas com haste verde.

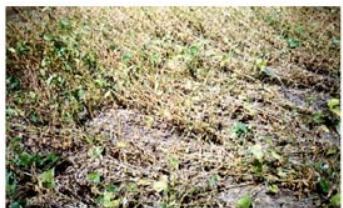

Figura 25 - Vista lateral de parcela com soja acamada. 


\section{RESULTADOS E DISCUSSÃO}

\subsection{Considerações Iniciais}

\subsubsection{Considerações sobre a precipitação pluvial e a temperatura média do ar durante o período de experimentação}

A soja é uma cultura sensível tanto ao excesso, como à escassez de umidade, em diferentes etapas do seu ciclo. Porém, devido às características do desenvolvimento de seu sistema radicular e ao período prolongado de florescimento, apresenta maior resistência a curtos períodos de estiagem, quando comparada a outras espécies cultivadas. Regiões com precipitações médias anuais de 700 a 1.200 mm, com boa distribuição (500 a 700 mm) durante o ciclo das plantas, são consideradas aptas para a cultura (Câmara, 2000).

Quanto à temperatura, esta exerce influência sobre todas as fases fenológicas da planta. A faixa térmica mais apropriada para o desenvolvimento da cultura situa-se entre $600^{\circ} \mathrm{C}$ e $2.400^{\circ} \mathrm{C}$. Este total é obtido através da soma diária das temperaturas médias diárias superiores a $15^{\circ} \mathrm{C}$ (temperatura base inferior), durante todo o ciclo vegetativo. Com relação à aptidão térmica regional, considera-se que uma determinada região não é recomendada para a cultura da soja, quando a temperatura média do mês mais quente for menor que $20^{\circ} \mathrm{C}$ (Berlato, 1981).

Assim sendo, o conhecimento da evolução dos principais elementos do clima é de fundamental importância para as pesquisas de campo, pois os mesmos interferem diretamente no desenvolvimento das plantas. Nas condições existentes da Estação Experimental Anhembi, foi possível acompanhar os dados pluviométricos durante o 
período de experimentação 2001/02, os quais foram obtidos com a coleta diária do volume de chuva captado em um pluviômetro instalado junto à área experimental (100 $\mathrm{cm}^{2}$ de área).

A Figura 26 ilustra a precipitação total quinzenal, servindo de subsídio para uma melhor interpretação dos resultados que serão apresentados posteriormente. É de extrema importância salientar que durante o ciclo cultural da soja não houve complementação de água para a cultura através de irrigação.

Na Figura 27, encontram-se os valores da temperatura média, sendo que estes foram coletados pela estação meteorológica do Departamento de Ciências Exatas, da USP/ESALQ, referente à cidade de Piracicaba-SP.

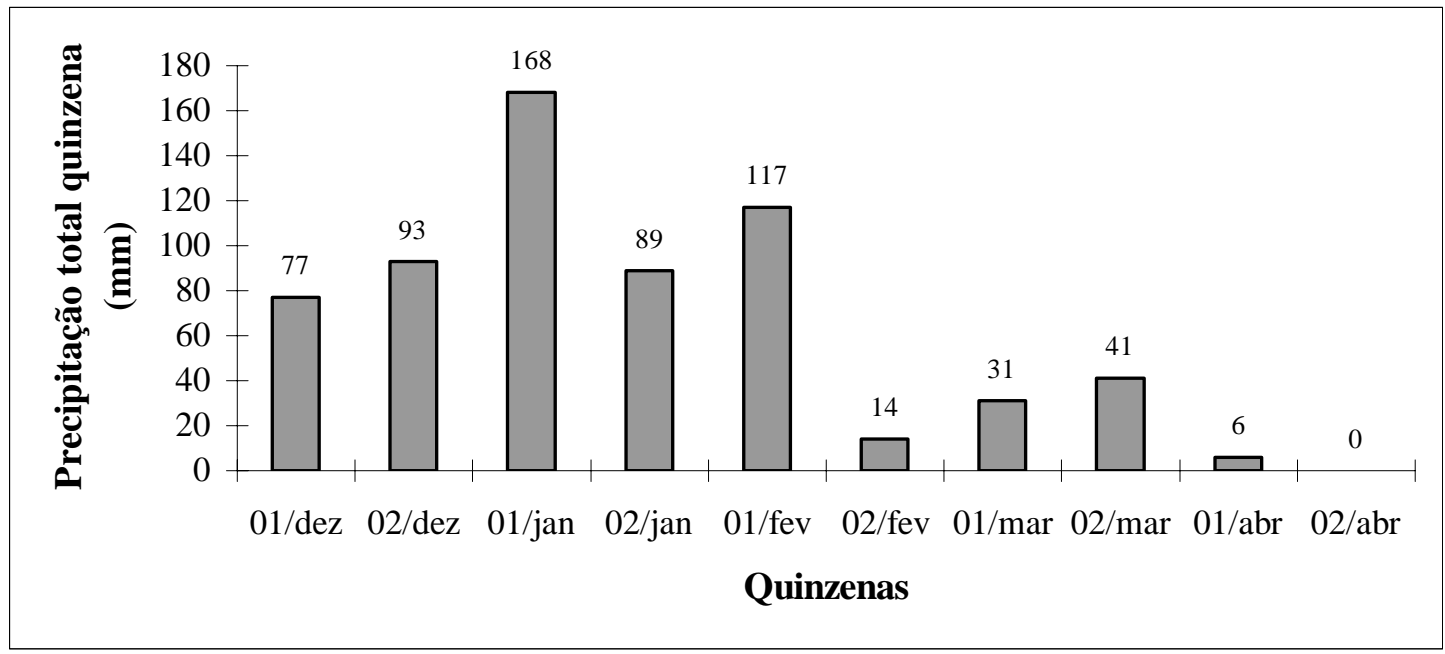

Figura 26 - Valores observados para precipitação total na área experimental, relativos às quinzenas correspondentes ao período de dezembro de 2001 a abril de 2002

Para este ano agrícola, o volume total coletado de precipitação durante os 127 dias entre o plantio e a colheita da soja foi de $637 \mathrm{~mm}$. Observando os dados da Figura 26, verifica-se a ocorrência de um período de adversidade climática, entre a segunda quinzena de fevereiro e a primeira quinzena de março, em que ocorreu um decréscimo acentuado da precipitação (veranico). Associado a este veranico, houve uma elevação da temperatura média, com valores de 26,1 e $25,5^{\circ} \mathrm{C}$ na primeira e segunda quinzena de 
março, respectivamente, o que pode ser verificado na Figura 27. Este período ocorreu no momento do enchimento de grãos, ou seja, no intenso acúmulo de matéria seca pelos grãos.

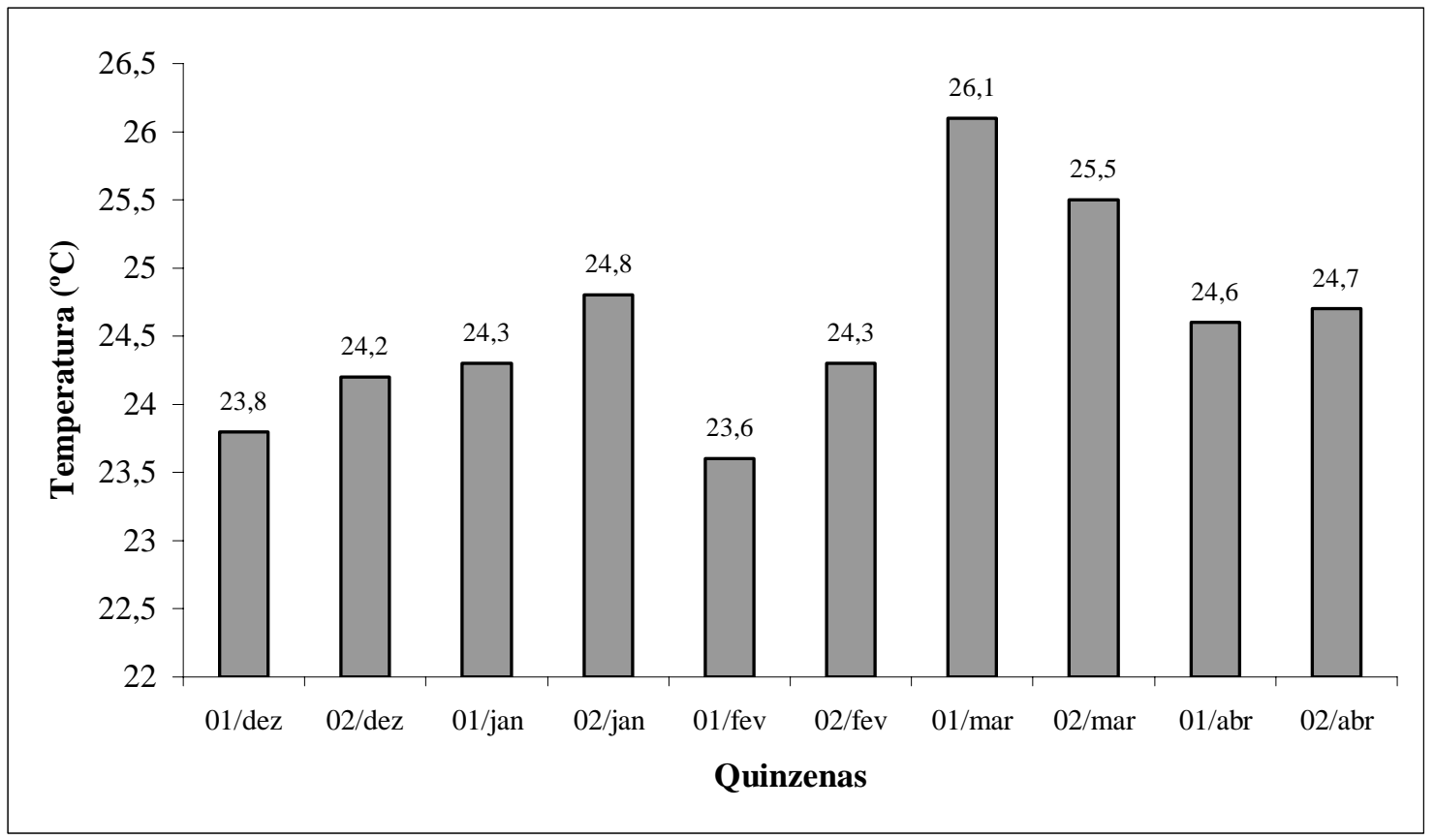

Figura 27 - Valores observados para temperatura média do ar, relativos às quinzenas correspondentes ao período de dezembro de 2001 a abril de 2002

\subsection{Produtividade de Matéria Seca do Capim-pé-de-galinha}

Na Tabela 5, encontram-se os valores observados para a produtividade de matéria seca do capim-pé-de-galinha.

Nota-se que não houve diferença estatística entre as médias dos diferentes tratamentos, mostrando que a antecipação da adubação da soja para o capim não trouxe incremento significativo da produção de matéria seca pelo mesmo. Entretanto, numericamente, observam-se alguns resultados interessantes. Os tratamentos 2, 3 e 4 
corresponderam à manutenção da dose total do fósforo na adubação de base da soja, com a antecipação progressiva da adubação potássica, 0, 25 e $50 \mathrm{~kg}$ de $\mathrm{K}_{2} \mathrm{O}$ por hectare, respectivamente. Neste último nível de antecipação (tratamento 4) a produção de matéria seca do capim-pé-de-galinha superou os $5.000 \mathrm{~kg} \mathrm{ha}^{-1}$ e foi superior ao tratamento 1 (controle) em $1.654 \mathrm{~kg} \mathrm{ha}^{-1}$.

Os tratamentos 5, 6 e 7 corresponderam à antecipação da metade da adubação fosfatada de base para a cultura da soja $\left(45 \mathrm{~kg}_{2} \mathrm{O}_{5} \mathrm{ha}^{-1}\right)$ associada, respectivamente à antecipação progressiva da adubação potássica. Nota-se que, numericamente, também a produção de matéria seca do Eleusine coracana aumentou progressivamente.

Para o nível máximo de antecipação da adubação fosfatada (90 kg $\left.\mathrm{P}_{2} \mathrm{O}_{5} \mathrm{ha}^{-1}\right)$, a antecipação progressiva da adubação potássica (tratamentos 8, 9 e 10) proporcionou, numericamente, ganhos progressivos de matéria seca do capim-pé-de-galinha, com produtividade máxima observada de $6.375 \mathrm{~kg} \mathrm{ha}^{-1}$ para o tratamento 10 , relativo à antecipação das doses totais de fósforo e potássio.

Esses resultados indicam que, com a antecipação da adubação fosfatada e potássica recomendada para a cultura da soja, a produção de matéria seca de Eleusine coracana pode ser incrementada. Indicam também, que a antecipação isolada da adubação potássica melhora a produção de matéria seca, porém, esta é incrementada quando P e K são antecipados conjuntamente. 
Tabela 5. Valores médios de produção de matéria seca do capim-pé-de-galinha (PMS) no momento da dessecação

\begin{tabular}{cccc}
\hline Tratamentos & Eleusine coracana & Soja & $\begin{array}{c}\text { PMS } \\
\text { (kg ha }^{-1} \text { ) }\end{array}$ \\
\hline 1 & $00 \mathrm{P}+00 \mathrm{~K}$ & $00 \mathrm{P}+00 \mathrm{~K}$ & 3.488 \\
2 & $00 \mathrm{P}+00 \mathrm{~K}$ & $90 \mathrm{P}+50 \mathrm{~K}^{1}$ & 4.886 \\
3 & $00 \mathrm{P}+25 \mathrm{~K}$ & $90 \mathrm{P}+25 \mathrm{~K}^{1}$ & 4.800 \\
4 & $00 \mathrm{P}+50 \mathrm{~K}$ & $90 \mathrm{P}+00 \mathrm{~K}^{1}$ & 5.142 \\
5 & $45 \mathrm{P}+00 \mathrm{~K}$ & $45 \mathrm{P}+50 \mathrm{~K}^{1}$ & 4.777 \\
6 & $45 \mathrm{P}+25 \mathrm{~K}$ & $45 \mathrm{P}+25 \mathrm{~K}^{1}$ & 5.210 \\
7 & $45 \mathrm{P}+50 \mathrm{~K}$ & $45 \mathrm{P}+00 \mathrm{~K}^{1}$ & 5.554 \\
8 & $90 \mathrm{P}+00 \mathrm{~K}$ & $00 \mathrm{P}+50 \mathrm{~K}^{1}$ & 4.967 \\
9 & $90 \mathrm{P}+25 \mathrm{~K}$ & $00 \mathrm{P}+25 \mathrm{~K}^{1}$ & 5.310 \\
10 & $90 \mathrm{P}+50 \mathrm{~K}$ & $00 \mathrm{P}+00 \mathrm{~K}^{1}$ & 6.375 \\
11 & $90 \mathrm{P}+50 \mathrm{~K}$ & $00 \mathrm{P}+00 \mathrm{~K}$ & 6.015 \\
12 & $00 \mathrm{P}+00 \mathrm{~K}{ }^{1}$ & $90 \mathrm{P}+50 \mathrm{~K}$ & 3.848 \\
${ }^{2}$ Não significativo para análise da variância. & & 5.031 \\
Média & & & $\mathrm{n} .{ }^{2}$ \\
P $>$ F & & & 22,15 \\
C.V. (\%) & & &
\end{tabular}

\subsection{Parâmetros Relativos a Pré-colheita da Soja}

Os valores médios observados para altura final de planta, estande final, ocorrência de plantas com haste verde e acamamento podem ser observados na Tabela 6. 
Tabela 6. Valores médios para altura final de planta (AFP), estande final (EF), acamamento (Ac) e ocorrência de plantas com haste verde (HV)

\begin{tabular}{|c|c|c|c|c|c|c|}
\hline Trat. & $\begin{array}{l}\text { Eleusine } \\
\text { coracana }\end{array}$ & Soja & $\begin{array}{l}\text { AFP } \\
(\mathbf{c m})\end{array}$ & $\begin{array}{c}\text { EF } \\
\text { n }^{\mathrm{o}} \text { pl. (m.l.) }\end{array}$ & $\begin{array}{c}\text { Ac } \\
\text { (nota) }\end{array}$ & $\begin{array}{c}\text { HV } \\
\text { (\% plantas) }\end{array}$ \\
\hline 1 & $00 \mathrm{P}+00 \mathrm{~K}$ & $00 \mathrm{P}+00 \mathrm{~K}$ & 76 & 20 & 1,33 & 32,14 \\
\hline 2 & $00 \mathrm{P}+00 \mathrm{~K}$ & $90 \mathrm{P}+50 \mathrm{~K}^{1}$ & 76 & 21 & 3,33 & 46,25 \\
\hline 3 & $00 \mathrm{P}+25 \mathrm{~K}$ & $90 \mathrm{P}+25 \mathrm{~K}^{1}$ & 78 & 19 & 2,67 & 59,31 \\
\hline 4 & $00 \mathrm{P}+50 \mathrm{~K}$ & $90 \mathrm{P}+00 \mathrm{~K}^{1}$ & 77 & 21 & 2,67 & 46,44 \\
\hline 5 & $45 \mathrm{P}+00 \mathrm{~K}$ & $45 \mathrm{P}+50 \mathrm{~K}^{1}$ & 80 & 19 & 2,67 & 59,23 \\
\hline 6 & $45 P+25 K$ & $45 \mathrm{P}+25 \mathrm{~K}^{1}$ & 79 & 19 & 3,00 & 63,27 \\
\hline 7 & $45 \mathrm{P}+50 \mathrm{~K}$ & $45 \mathrm{P}+00 \mathrm{~K}^{1}$ & 77 & 20 & 3,00 & 42,73 \\
\hline 8 & $90 \mathrm{P}+00 \mathrm{~K}$ & $00 \mathrm{P}+50 \mathrm{~K}^{1}$ & 78 & 21 & 2,33 & 58,73 \\
\hline 9 & $90 \mathrm{P}+25 \mathrm{~K}$ & $00 \mathrm{P}+25 \mathrm{~K}^{1}$ & 76 & 18 & 3,00 & 41,70 \\
\hline 10 & $90 \mathrm{P}+50 \mathrm{~K}$ & $00 \mathrm{P}+00 \mathrm{~K}^{1}$ & 79 & 20 & 2,67 & 51,24 \\
\hline 11 & $90 \mathrm{P}+50 \mathrm{~K}^{1}$ & $00 \mathrm{P}+00 \mathrm{~K}$ & 76 & 18 & 2,67 & 55,30 \\
\hline 12 & $00 \mathrm{P}+00 \mathrm{~K}^{1}$ & $90 \mathrm{P}+50 \mathrm{~K}$ & 74 & 21 & 3,00 & 44,41 \\
\hline Média & & & 77 & 20 & 2,69 & 50,06 \\
\hline $\mathrm{P}>\mathrm{F}$ & & & n.s. ${ }^{2}$ & n.s. ${ }^{2}$ & n.s. ${ }^{2}$ & n.s. ${ }^{2}$ \\
\hline C.V. (\%) & & & 4,13 & 9,86 & 25,37 & 27,59 \\
\hline
\end{tabular}

${ }^{1}$ Adubação foliar com micronutrientes;

${ }^{2}$ Não significativo para análise da variância.

Analisando-se os dados da Tabela 6, observa-se que a altura final de planta não foi influenciada pela adubação antecipada. Não houve diferença estatística também para o estande final, revelando que os tratamentos aplicados não interferiram com esta variável. Outrossim, a uniformidade de estande entre os tratamentos revela que as operações de instalação e condução do experimento ocorreram dentro dos padrões esperados. Não houve diferença estatística, também para o acamamento, mostrando que a antecipação da adubação não interferiu nesta variável. Para a porcentagem de ocorrência de haste verde na soja, não houve diferença estatística entre as médias de 
tratamentos, revelando não existir efeito da adubação antecipada sobre a ocorrência das mesmas na soja.

\subsection{Parâmetros Relativos aos Componentes da Produção de Soja}

\subsubsection{Número de ramificações, vagens chochas e total de vagens por planta}

Na Tabela 7, encontram-se os valores médios para o número de ramificações por planta, número de vagens chochas por planta e o número total de vagens por planta.

Os resultados observados até o momento, relativos à produção de matéria seca pelo capim-pé-de-galinha e ao número de vagens chochas e número total de vagens formadas por planta de soja, parecem indicar a existência de uma ação sinérgica e positiva da antecipação parcial ou total das adubações fosfatada e potássica da cultura da soja para a semeadura do capim-pé-de-galinha.

Observando-se os dados da Tabela 7, nota-se que não houve influência da antecipação da adubação sobre o número de ramificações na soja. Porém, para as variáveis, número de vagens chochas e número total de vagens por planta, a análise de variância revelou médias significativamente diferentes entre tratamentos e com resultados interessantes.

Em relação ao tratamento controle a antecipação total e exclusiva da adubação potássica da soja para o capim-pé-de-galinha (tratamento 4) dobrou o número de vagens chochas por planta, sem no entanto, interferir significativamente no número total de vagens formadas por planta. Embora para os demais tratamentos não tenham sido constatadas diferenças significativas, nota-se que em relação aos valores extremos revelados pelos tratamentos 1 e 4, a antecipação parcial ou total da adubação potássica em conjunto com a antecipação parcial ou total da adubação fosfatada da soja para o capim Eleusine coracana, amenizou a ocorrência de vagens chochas.

Com relação ao número total de vagens formadas pela planta de soja, nota-se novamente, que a antecipação parcial ou total, porém em conjunto, da adubação fosfatada e potássica da soja para o capim-pé-de-galinha melhorou, numericamente, o 
desempenho da soja quanto à formação de vagens. Nota-se ainda, que a antecipação total da adubação fosfatada e potássica (tratamento 10) aumentou significativamente o número total de vagens por planta perante a antecipação parcial e exclusiva da adubação potássica (tratamento 3) e a ausência total de adubação do agroecossistema estudado (tratamento 1).

Tabela 7. Valores médios para número de ramificações por planta (NRP), número de vagens chochas por planta (NVCP) e número total de vagens por planta (NTV)

\begin{tabular}{|c|c|c|c|c|c|}
\hline Tratamentos & $\begin{array}{l}\text { Eleusine } \\
\text { coracana }\end{array}$ & Soja & NRP & NVCP & NTV \\
\hline 1 & $00 \mathrm{P}+00 \mathrm{~K}$ & $00 \mathrm{P}+00 \mathrm{~K}$ & 6 & $3 b^{3}$ & $45 \quad c^{3}$ \\
\hline 2 & $00 \mathrm{P}+00 \mathrm{~K}$ & $90 \mathrm{P}+50 \mathrm{~K}^{1}$ & 6 & $4 \mathrm{ab}$ & 51 abc \\
\hline 3 & $00 \mathrm{P}+25 \mathrm{~K}$ & $90 \mathrm{P}+25 \mathrm{~K}^{1}$ & 6 & $5 \mathrm{ab}$ & 46 bc \\
\hline 4 & $00 \mathrm{P}+50 \mathrm{~K}$ & $90 \mathrm{P}+00 \mathrm{~K}^{1}$ & 6 & $6 \mathrm{a}$ & 53 abc \\
\hline 5 & $45 P+00 K$ & $45 \mathrm{P}+50 \mathrm{~K}^{1}$ & 6 & $5 \mathrm{ab}$ & 50 abc \\
\hline 6 & $45 \mathrm{P}+25 \mathrm{~K}$ & $45 \mathrm{P}+25 \mathrm{~K}^{1}$ & 6 & $4 \mathrm{ab}$ & 52 abc \\
\hline 7 & $45 \mathrm{P}+50 \mathrm{~K}$ & $45 \mathrm{P}+00 \mathrm{~K}^{1}$ & 6 & $4 \mathrm{ab}$ & 55 abc \\
\hline 8 & $90 \mathrm{P}+00 \mathrm{~K}$ & $00 \mathrm{P}+50 \mathrm{~K}^{1}$ & 6 & $5 \mathrm{ab}$ & $57 \mathrm{ab}$ \\
\hline 9 & $90 \mathrm{P}+25 \mathrm{~K}$ & $00 \mathrm{P}+25 \mathrm{~K}^{1}$ & 6 & $5 \mathrm{ab}$ & $55 \mathrm{abc}$ \\
\hline 10 & $90 \mathrm{P}+50 \mathrm{~K}$ & $00 \mathrm{P}+00 \mathrm{~K}^{1}$ & 6 & $4 \mathrm{ab}$ & $60 \mathrm{a}$ \\
\hline 11 & $90 \mathrm{P}+50 \mathrm{~K}^{1}$ & $00 \mathrm{P}+00 \mathrm{~K}$ & 6 & $4 \mathrm{ab}$ & 52 abc \\
\hline 12 & $00 \mathrm{P}+00 \mathrm{~K}^{1}$ & $90 \mathrm{P}+50 \mathrm{~K}$ & 6 & $5 \mathrm{ab}$ & 54 abc \\
\hline Média & & & 6 & 5 & 52 \\
\hline $\mathrm{P}>\mathrm{F}$ & & & n.s. ${ }^{2}$ & $*$ & $*$ \\
\hline C.V. (\%) & & & 10,97 & 20,47 & 7,91 \\
\hline
\end{tabular}

${ }^{1}$ Adubação foliar com micronutrientes;

${ }^{2}$ Não significativo para análise da variância;

${ }^{3}$ Médias seguidas por letras distintas diferem entre si pelo teste de Tukey a 5\%. 


\subsubsection{Número e peso total de grãos por planta}

Na Tabela 8 observam-se os valores médios para o número total e o respectivo peso total de grãos por planta, notando-se diferenças significativas entre tratamentos para ambos os parâmetros avaliados.

Tabela 8. Valores médios para o número total de grãos por planta (NTGP) e peso total de grãos por planta (PTGP)

\begin{tabular}{|c|c|c|c|c|}
\hline Tratamentos & $\begin{array}{l}\text { Eleusine } \\
\text { coracana }\end{array}$ & Soja & NTGP & PTGP (g) \\
\hline 1 & $00 \mathrm{P}+00 \mathrm{~K}$ & $00 \mathrm{P}+00 \mathrm{~K}$ & $93 \quad b^{2}$ & $14,15 \quad c^{2}$ \\
\hline 2 & $00 \mathrm{P}+00 \mathrm{~K}$ & $90 \mathrm{P}+50 \mathrm{~K}^{1}$ & 110 abc & 16,22 abc \\
\hline 3 & $00 \mathrm{P}+25 \mathrm{~K}$ & $90 \mathrm{P}+25 \mathrm{~K}^{1}$ & $91 \quad \mathrm{c}$ & 14,76 bc \\
\hline 4 & $00 \mathrm{P}+50 \mathrm{~K}$ & $90 \mathrm{P}+00 \mathrm{~K}^{1}$ & 106 abc & 16,59 abc \\
\hline 5 & $45 \mathrm{P}+00 \mathrm{~K}$ & $45 \mathrm{P}+50 \mathrm{~K}^{1}$ & 102 abc & 16,17 abc \\
\hline 6 & $45 P+25 K$ & $45 \mathrm{P}+25 \mathrm{~K}^{1}$ & 109 abc & 16,94 abc \\
\hline 7 & $45 \mathrm{P}+50 \mathrm{~K}$ & $45 \mathrm{P}+00 \mathrm{~K}^{1}$ & 116 abc & $18,09 \mathrm{ab}$ \\
\hline 8 & $90 \mathrm{P}+00 \mathrm{~K}$ & $00 \mathrm{P}+50 \mathrm{~K}^{1}$ & $119 \mathrm{ab}$ & 18,24 ab \\
\hline 9 & $90 \mathrm{P}+25 \mathrm{~K}$ & $00 \mathrm{P}+25 \mathrm{~K}^{1}$ & 115 abc & 16,72 abc \\
\hline 10 & $90 \mathrm{P}+50 \mathrm{~K}$ & $00 \mathrm{P}+00 \mathrm{~K}^{1}$ & 127 a & 19,34 a \\
\hline 11 & $90 \mathrm{P}+50 \mathrm{~K}^{1}$ & $00 \mathrm{P}+00 \mathrm{~K}$ & 108 abc & 16,60 abc \\
\hline 12 & $00 \mathrm{P}+00 \mathrm{~K}^{1}$ & $90 \mathrm{P}+50 \mathrm{~K}$ & 108 abc & 16,88 abc \\
\hline Média & & & 108,70 & 16,72 \\
\hline $\mathrm{P}>\mathrm{F}$ & & & $*$ & $*$ \\
\hline C.V. (\%) & & & 8,18 & 7,18 \\
\hline
\end{tabular}

${ }^{1}$ Adubação foliar com micronutrientes;

${ }^{2}$ Médias seguidas por letras distintas diferem entre si pelo teste de Tukey a 5\%.

A antecipação exclusiva da adubação potássica de apenas $25 \mathrm{~kg}$ de $\mathrm{K}_{2} \mathrm{O}$ por hectare (tratamento 3) não melhorou o desempenho da soja em relação à quantidade de grãos formados por planta, quando comparada à ausência total de adubação do capim- 
pé-de-galinha (tratamento 1). Observou-se o mesmo desempenho do tratamento 3 em comparação ao tratamento controle, quanto ao respectivo peso do total de grãos formados por planta.

É interessante observar que a antecipação parcial e exclusiva da adubação potássica no Eleusine coracana (tratamento 3) também proporcionou o menor número total de vagens formadas por planta (Tabela 7), desempenho este, oposto àquele observado para a antecipação total das adubações fosfatada e potássica sobre o capimpé-de-galinha (tratamento 10).

Destaque-se que em relação aos tratamentos 1 e 3, a antecipação total das adubações fosfatada e potássica proporcionou a maior quantidade de grãos formados por planta e o respectivo maior peso.

\subsubsection{Número de vagens de 3 cavidades com 3, 2 e 1 grão}

O número de vagens por planta, o número de grãos por vagem e o peso médio do grão constituem os componentes da produção por planta. Na ausência de limitações ao crescimento, cada cultivar tende a expressar ao máximo o seu potencial fenotípico de alta produtividade, geralmente, através de grande quantidade de vagens, sendo estas bem granadas. Em condições favoráveis o limite dessa expressão de produtividade passa a ser regulado pela competição interna entre os componentes da produção da planta, onde normalmente, observa-se formação de sementes menores e, portanto, individualmente mais leves.

Na Tabela 9, encontra-se os valores médios para o número de vagens de soja de três cavidades contendo três, dois e um grão. Nota-se que o valor médio observado para o número de vagens com 3 grãos correspondeu a 66,7\% do total de vagens contendo três cavidades, tendo portanto, maior participação no cômputo da produtividade da planta, seguido pelas vagens de três cavidades com 2 grãos (24,2\%) e com um grão (9,1\%).

As diferenças significativas entre tratamentos ocorreram apenas na categoria vagem com três grãos. Em comparação ao tratamento controle e à antecipação parcial de 25 kg de $\mathrm{K}_{2} \mathrm{O}$ por hectare para o capim-pé-de-galinha (tratamento 3), a antecipação total 
e exclusiva da adubação fosfatada (tratamento 8) e a antecipação total das adubações fosfatada e potássica (tratamento 10), aumentaram significativamente o número de vagens por planta com três cavidades contendo três grãos (Tabela 9).

Tabela 9. Valores médios para o número de vagens de 3 cavidades com 3 grãos (V. 3x3), 2 grãos (V. 3x2) e 1 grão (V. 3x1)

\begin{tabular}{|c|c|c|c|c|c|}
\hline Tratamentos & $\begin{array}{l}\text { Eleusine } \\
\text { coracana }\end{array}$ & Soja & V. 3x3 & V. $3 \times 2$ & V. 3x1 \\
\hline 1 & $00 \mathrm{P}+00 \mathrm{~K}$ & $00 \mathrm{P}+00 \mathrm{~K}$ & $18 \quad b^{3}$ & 8 & 2 \\
\hline 2 & $00 \mathrm{P}+00 \mathrm{~K}$ & $90 \mathrm{P}+50 \mathrm{~K}^{1}$ & $23 \mathrm{ab}$ & 7 & 3 \\
\hline 3 & $00 \mathrm{P}+25 \mathrm{~K}$ & $90 \mathrm{P}+25 \mathrm{~K}^{1}$ & $17 \quad b$ & 7 & 3 \\
\hline 4 & $00 \mathrm{P}+50 \mathrm{~K}$ & $90 \mathrm{P}+00 \mathrm{~K}^{1}$ & $21 \mathrm{ab}$ & 8 & 3 \\
\hline 5 & $45 \mathrm{P}+00 \mathrm{~K}$ & $45 \mathrm{P}+50 \mathrm{~K}^{1}$ & $21 \mathrm{ab}$ & 7 & 3 \\
\hline 6 & $45 \mathrm{P}+25 \mathrm{~K}$ & $45 \mathrm{P}+25 \mathrm{~K}^{1}$ & $22 \mathrm{ab}$ & 9 & 4 \\
\hline 7 & $45 \mathrm{P}+50 \mathrm{~K}$ & $45 \mathrm{P}+00 \mathrm{~K}^{1}$ & $23 \mathrm{ab}$ & 9 & 3 \\
\hline 8 & $90 \mathrm{P}+00 \mathrm{~K}$ & $00 \mathrm{P}+50 \mathrm{~K}^{1}$ & 24 a & 8 & 4 \\
\hline 9 & $90 \mathrm{P}+25 \mathrm{~K}$ & $00 \mathrm{P}+25 \mathrm{~K}^{1}$ & $23 \mathrm{ab}$ & 9 & 3 \\
\hline 10 & $90 \mathrm{P}+50 \mathrm{~K}$ & $00 \mathrm{P}+00 \mathrm{~K}^{1}$ & 26 a & 8 & 4 \\
\hline 11 & $90 \mathrm{P}+50 \mathrm{~K}^{1}$ & $00 \mathrm{P}+00 \mathrm{~K}$ & $21 \mathrm{ab}$ & 8 & 4 \\
\hline 12 & $00 \mathrm{P}+00 \mathrm{~K}^{1}$ & $90 \mathrm{P}+50 \mathrm{~K}$ & $21 \mathrm{ab}$ & 8 & 3 \\
\hline Média & & & 22 & 8 & 3 \\
\hline $\mathrm{P}>\mathrm{F}$ & & & $*$ & n.s. ${ }^{2}$ & n.s. ${ }^{2}$ \\
\hline C.V. (\%) & & & 9,67 & 18,42 & 22,84 \\
\hline
\end{tabular}

\footnotetext{
${ }^{1}$ Adubação foliar com micronutrientes;

${ }^{2}$ Não significativo para análise da variância;

${ }^{3}$ Médias seguidas por letras distintas diferem entre si pelo teste de Tukey a 5\%.
} 


\subsubsection{Número de vagens de 2 cavidades com 2 e 1 grão e número de vagens de 1 cavidade com 1 grão}

Na Tabela 10 são apresentados os valores médios para o número de vagens de soja de duas cavidades contendo dois e um grão e número de vagens com apenas uma cavidade e, portanto, um grão.

No cômputo geral do total de vagens granadas formadas por planta de soja, o somatório dos valores médios das Tabelas 9 e 10 revela os seguintes resultados: 48 vagens granadas por planta, das quais 22 (45,8 \%) com três cavidades e três grãos; 11 (22,9 \%) com duas cavidades e dois grãos; 8 (16,7 \%) com três cavidades e dois grãos; 3 (6,2 \%) com três cavidades e um grão; 3 (6,2 \%) com duas cavidades e um grão e apenas uma vagem (2,2 \%) contendo uma cavidade e um grão.

Considerando-se apenas o número de grãos por vagem, os valores médios apresentados nas Tabelas 9 e 10 revelam: 22 (45,8 \%) de vagens contendo três grãos; 19 (39,6 \%) de vagens contendo dois grãos e 7 (14,6 \%) vagens contendo apenas um grão. Esses resultados indicam que predominaram vagens bem granadas nas plantas de soja conduzidas durante o período de experimentação.

Novamente, apenas para a categoria de melhor granação, isto é, para as vagens de duas cavidades contendo dois grãos é que se observaram diferenças significativas entre tratamentos (Tabela 10). Nota-se desta vez, em comparação ao tratamento controle e à antecipação exclusiva e parcial da adubação fosfatada (tratamento 5), melhor granação das vagens de duas cavidades e com dois grãos proporcionada pela antecipação parcial da adubação fosfatada e total da potássica (tratamento 7); antecipação total e exclusiva da fosfatada (tratamento 8) e antecipação total das adubações fosfatada e potássica (tratamento 10).

Apesar da ocorrência de veranico durante a segunda quinzena de fevereiro de 2002, acredita-se que a água armazenada no solo da área experimental tenha atendido aos requerimentos hídricos do período de intenso acúmulo de matéria seca na forma de grãos. 
Tabela 10. Valores médios para o número de vagens de 2 cavidades com 2 (V. 2x2) e 1 grão (V. 2x1) e número de vagens de 1 cavidade com 1 grão (V. 1x1)

\begin{tabular}{|c|c|c|c|c|c|}
\hline Tratamentos & $\begin{array}{l}\text { Eleusine } \\
\text { coracana }\end{array}$ & Soja & V. $2 \times 2$ & V. $2 \times 1$ & V. $1 \times 1$ \\
\hline 1 & $00 \mathrm{P}+00 \mathrm{~K}$ & $00 \mathrm{P}+00 \mathrm{~K}$ & $9,3 \quad \mathrm{~cd}^{3}$ & 3 & 1 \\
\hline 2 & $00 \mathrm{P}+00 \mathrm{~K}$ & $90 \mathrm{P}+50 \mathrm{~K}^{1}$ & 10,6 abcd & 3 & 1 \\
\hline 3 & $00 \mathrm{P}+25 \mathrm{~K}$ & $90 \mathrm{P}+25 \mathrm{~K}^{1}$ & 9,9 bcd & 2 & 2 \\
\hline 4 & $00 \mathrm{P}+50 \mathrm{~K}$ & $90 \mathrm{P}+00 \mathrm{~K}^{1}$ & 9,8 bcd & 3 & 2 \\
\hline 5 & $45 \mathrm{P}+00 \mathrm{~K}$ & $45 \mathrm{P}+50 \mathrm{~K}^{1}$ & 8,9 & 2 & 2 \\
\hline 6 & $45 \mathrm{P}+25 \mathrm{~K}$ & $45 \mathrm{P}+25 \mathrm{~K}^{1}$ & 9,9 bcd & 3 & 1 \\
\hline 7 & $45 \mathrm{P}+50 \mathrm{~K}$ & $45 \mathrm{P}+00 \mathrm{~K}^{1}$ & 11,5 abc & 3 & 1 \\
\hline 8 & $90 \mathrm{P}+00 \mathrm{~K}$ & $00 \mathrm{P}+50 \mathrm{~K}^{1}$ & $12,4 \quad \mathrm{a}$ & 3 & 1 \\
\hline 9 & $90 \mathrm{P}+25 \mathrm{~K}$ & $00 \mathrm{P}+25 \mathrm{~K}^{1}$ & 11,3 abcd & 2 & 1 \\
\hline 10 & $90 \mathrm{P}+50 \mathrm{~K}$ & $00 \mathrm{P}+00 \mathrm{~K}^{1}$ & 12,9 a & 3 & 2 \\
\hline 11 & $90 \mathrm{P}+50 \mathrm{~K}^{1}$ & $00 \mathrm{P}+00 \mathrm{~K}$ & 10,7 abcd & 3 & 1 \\
\hline 12 & $00 \mathrm{P}+00 \mathrm{~K}^{1}$ & $90 \mathrm{P}+50 \mathrm{~K}$ & $11,9 \quad a b$ & 3 & 2 \\
\hline Média & & & 10,8 & 3 & 1 \\
\hline $\mathrm{P}>\mathrm{F}$ & & & * & n.s. ${ }^{2}$ & n.s. ${ }^{2}$ \\
\hline C.V. (\%) & & & 7,92 & 23,86 & 36,53 \\
\hline
\end{tabular}

${ }^{1}$ Adubação foliar com micronutrientes;

${ }^{2}$ Não significativo para análise da variância;

${ }^{3}$ Médias seguidas por letras distintas diferem entre si pelo teste de Tukey a 5\%.

\subsection{Produtividade agrícola da soja e peso de mil grãos}

Na Tabela 11 são apresentados os valores médios observados para a produtividade agrícola da soja. Também, são reapresentados os valores médios observados para a produtividade agrícola de matéria seca do capim Eleusine coracana. Da mesma forma que para este último parâmetro, a análise da variância não revelou valores de $\mathrm{F}$ significativos para efeito de tratamentos, indicando que a antecipação parcial ou total da 
adubação fosfatada e potássica da semeadura da soja para a semeadura do capim-pé-degalinha, em sua primeira realização, não interferiram com a produtividade agrícola de soja, cultivar BRS-133, instalado pela primeira vez em sistema de semeadura direta sobre a palhada do capim Eleusine coracana.

Tabela 11. Produção de matéria seca do Eleusine coracana, produtividade agrícola da soja (P.A.), e respectivos valores de referência (V.R.)

\begin{tabular}{|c|c|c|c|c|c|c|}
\hline Tratamentos & $\begin{array}{l}\text { Eleusine } \\
\text { coracana }\end{array}$ & Soja & $\begin{array}{l}\text { PMS Capim } \\
\left(\mathrm{kg} \mathrm{ha}^{-1}\right)\end{array}$ & $\begin{array}{l}\text { V.R. } \\
\text { (\%) }\end{array}$ & $\begin{array}{c}\text { P.A. } \\
\left(\mathrm{kg} \mathrm{ha}^{-1}\right)\end{array}$ & $\begin{array}{l}\text { V.R. } \\
\text { (\%) }\end{array}$ \\
\hline 1 & $00 \mathrm{P}+00 \mathrm{~K}$ & $00 \mathrm{P}+00 \mathrm{~K}$ & 3.488 & 100,0 & 3.354 & 100,0 \\
\hline 2 & $00 \mathrm{P}+00 \mathrm{~K}$ & $90 \mathrm{P}+50 \mathrm{~K}^{1}$ & 4.886 & 140,1 & 3.304 & 98,5 \\
\hline 3 & $00 \mathrm{P}+25 \mathrm{~K}$ & $90 \mathrm{P}+25 \mathrm{~K}^{1}$ & 4.800 & 137,6 & 3.696 & 110,2 \\
\hline 4 & $00 \mathrm{P}+50 \mathrm{~K}$ & $90 \mathrm{P}+00 \mathrm{~K}^{1}$ & 5.142 & 147,4 & 3.479 & 103,7 \\
\hline 5 & $45 \mathrm{P}+00 \mathrm{~K}$ & $45 \mathrm{P}+50 \mathrm{~K}^{1}$ & 4.777 & 137,0 & 3.629 & 108,2 \\
\hline 6 & $45 \mathrm{P}+25 \mathrm{~K}$ & $45 \mathrm{P}+25 \mathrm{~K}^{1}$ & 5.210 & 149,4 & 3.578 & 106,7 \\
\hline 7 & $45 \mathrm{P}+50 \mathrm{~K}$ & $45 \mathrm{P}+00 \mathrm{~K}^{1}$ & 5.554 & 159,2 & 3.527 & 105,2 \\
\hline 8 & $90 \mathrm{P}+00 \mathrm{~K}$ & $00 \mathrm{P}+50 \mathrm{~K}^{1}$ & 4.967 & 142,4 & 3.599 & 107,3 \\
\hline 9 & $90 \mathrm{P}+25 \mathrm{~K}$ & $00 \mathrm{P}+25 \mathrm{~K}^{1}$ & 5.310 & 152,2 & 3.493 & 104,1 \\
\hline 10 & $90 \mathrm{P}+50 \mathrm{~K}$ & $00 \mathrm{P}+00 \mathrm{~K}^{1}$ & 6.375 & 182,8 & 3.403 & 101,5 \\
\hline 11 & $90 \mathrm{P}+50 \mathrm{~K}^{1}$ & $00 \mathrm{P}+00 \mathrm{~K}$ & 6.015 & 172,4 & 3.500 & 104,4 \\
\hline 12 & $00 \mathrm{P}+00 \mathrm{~K}^{1}$ & $90 \mathrm{P}+50 \mathrm{~K}$ & 3.848 & 110,3 & 3.632 & 108,3 \\
\hline Média & & & 5.031 & & 3.516 & \\
\hline $\mathrm{P}>\mathrm{F}$ & & & n.s. ${ }^{2}$ & & n.s. ${ }^{2}$ & \\
\hline C.V. (\%) & & & 22,15 & & 4,73 & \\
\hline
\end{tabular}

\footnotetext{
${ }^{1}$ Adubação foliar com micronutrientes;

${ }^{2}$ Não significativo para análise da variância.
}

A ausência de resposta da soja à adubação fosfatada e potássica por ocasião da semeadura também foi verificado por Kurihara et al. (1998), em experimentos conduzidos na safra 96/97, utilizando solos de alta fertilidade, em três unidades de mapeamento: LATOSSOLO ROXO distrófico epieutrófico (LRd, em Fátima do Sul, 
MS), LATOSSOLO ROXO álico epieutrófico (LRa, em Ponta Porã, MS, distrito de Guaíba) e LATOSSOLO ROXO eutrófico (LRe, em Dourados, MS, distrito de Panambi), aonde o sistema de semeadura direta vinha sendo adotado há três, sete e doze anos, respectivamente.

Na Tabela 12 são apresentados os valores médios observados para o peso de mil grãos de soja. Também são reapresentados os valores médios observados para a produtividade agrícola de matéria seca do capim Eleusine coracana. Da mesma forma que para este último parâmetro, a análise da variância não revelou valores de $\mathrm{F}$ significativos para efeito de tratamentos, indicando que a antecipação parcial ou total da adubação fosfatada e potássica da semeadura da soja para a semeadura do capim-pé-degalinha, em sua primeira realização, não interferiram com o acúmulo de matéria seca pelos grãos em formação. 
Tabela 12. Produção de matéria seca do Eleusine coracana, peso de mil grãos (P 1000) e respectivos valores de referência (V.R.)

\begin{tabular}{|c|c|c|c|c|c|c|}
\hline Tratamentos & $\begin{array}{l}\text { Eleusine } \\
\text { coracana }\end{array}$ & Soja & $\begin{array}{l}\text { PMS Capim } \\
\left(\mathrm{kg} \mathrm{ha}^{-1}\right)\end{array}$ & $\begin{array}{l}\text { V.R. } \\
(\%)\end{array}$ & $\begin{array}{c}\text { P } 1000 \\
\text { (g) }\end{array}$ & $\begin{array}{l}\text { V.R. } \\
(\%)\end{array}$ \\
\hline 1 & $00 \mathrm{P}+00 \mathrm{~K}$ & $00 \mathrm{P}+00 \mathrm{~K}$ & 3.488 & 100,0 & 145,89 & 100,0 \\
\hline 2 & $00 \mathrm{P}+00 \mathrm{~K}$ & $90 \mathrm{P}+50 \mathrm{~K}^{1}$ & 4.886 & 140,1 & 139,94 & 95,9 \\
\hline 3 & $00 \mathrm{P}+25 \mathrm{~K}$ & $90 \mathrm{P}+25 \mathrm{~K}^{1}$ & 4.800 & 137,6 & 146,23 & 100,2 \\
\hline 4 & $00 \mathrm{P}+50 \mathrm{~K}$ & $90 \mathrm{P}+00 \mathrm{~K}^{1}$ & 5.142 & 147,4 & 146,26 & 100,3 \\
\hline 5 & $45 \mathrm{P}+00 \mathrm{~K}$ & $45 \mathrm{P}+50 \mathrm{~K}^{1}$ & 4.777 & 137,0 & 143,40 & 98,3 \\
\hline 6 & $45 \mathrm{P}+25 \mathrm{~K}$ & $45 \mathrm{P}+25 \mathrm{~K}^{1}$ & 5.210 & 149,4 & 144,58 & 99,1 \\
\hline 7 & $45 \mathrm{P}+50 \mathrm{~K}$ & $45 \mathrm{P}+00 \mathrm{~K}^{1}$ & 5.554 & 159,2 & 141,31 & 96,9 \\
\hline 8 & $90 \mathrm{P}+00 \mathrm{~K}$ & $00 \mathrm{P}+50 \mathrm{~K}^{1}$ & 4.967 & 142,4 & 146,13 & 100,2 \\
\hline 9 & $90 P+25 K$ & $00 \mathrm{P}+25 \mathrm{~K}^{1}$ & 5.310 & 152,2 & 142,71 & 97,8 \\
\hline 10 & $90 \mathrm{P}+50 \mathrm{~K}$ & $00 \mathrm{P}+00 \mathrm{~K}^{1}$ & 6.375 & 182,8 & 145,92 & 100,0 \\
\hline 11 & $90 \mathrm{P}+50 \mathrm{~K}^{1}$ & $00 \mathrm{P}+00 \mathrm{~K}$ & 6.015 & 172,4 & 147,57 & 101,2 \\
\hline 12 & $00 \mathrm{P}+00 \mathrm{~K}^{1}$ & $90 \mathrm{P}+50 \mathrm{~K}$ & 3.848 & 110,3 & 142,91 & 98,0 \\
\hline Média & & & 5.031 & & 144,40 & \\
\hline $\mathrm{P}>\mathrm{F}$ & & & n.s. ${ }^{2}$ & & n.s. ${ }^{2}$ & \\
\hline C.V. (\%) & & & 22,15 & & 3,23 & \\
\hline
\end{tabular}

${ }^{1}$ Adubação foliar com micronutrientes;

${ }^{2}$ Não significativo para análise da variância.

\subsection{Considerações Finais}

Apesar do período de veranico detectado durante a segunda quinzena do mês de fevereiro de 2002, acredita-se, com base no desempenho da granação das vagens (Tabelas 7, 9 e 10) e nos resultados observados para os níveis de produtividade agrícola e o peso de mil grãos de soja (Tabelas 11 e 12), que não houve interferência do curto período de seca quanto aos efeitos de tratamentos sobre os parâmetros avaliados. 
A análise seqüencial dos resultados observados no primeiro ano de experimentação (Tabelas 5 a 12) revela os seguintes resultados:

a. Numericamente, a antecipação progressiva da adubação potássica da semeadura da soja para a semeadura do capim Eleusine coracana (L.) Gaertn., com ou sem a correspondente antecipação da adubação fosfatada, proporcionou incrementos na produtividade de matéria seca do capim-pé-de-galinha, variáveis de 37 a 83\%, sem no entanto, a deteç̧ão de diferenças significativas entre os tratamentos.

b. Em comparação ao tratamento controle, parâmetros como produtividade de matéria seca do capim-pé-de-galinha; número total de vagens e de grãos formados por planta; peso total dos grãos formados por planta e granação completa de vagens com três e duas cavidades, foram favorecidos pela antecipação total e exclusiva da adubação fosfatada (tratamento 8) e pela antecipação total das adubações fosfatada e potássica (tratamento 10), da semeadura da soja para a semeadura do capim Eleusine coracana (L.) Gaertn..

c. Finalmente, a utilização do sistema de semeadura direta, através da semeadura da soja sobre a palhada do capim Eleusine coracana (L.) Gaertn., em um LATOSSOLO AMARELO Distrófico, cultivado dessa forma pela primeira vez, possibilita a obtenção de média produtividade de matéria seca de capim-pé-degalinha e de média produtividade de grãos de soja. 


\section{CONCLUSÕES}

- As adubações fosfatada e potássica da cultura da soja, antecipadas parcial ou totalmente para a semeadura do capim Eleusine coracana (L.) Gaertn., podem incrementar a produtividade agrícola de matéria seca do capim-pé-de-galinha.

- Quando adotada pela primeira vez, a antecipação parcial ou total das adubações fosfatada e potássica da soja para a semeadura do Eleusine coracana (L.) Gaertn., não reduz a produtividade agrícola de grãos de soja.

- Trabalhos de pesquisa agronômica envolvendo estudos sobre adubação de agroecossistemas são de execução e interpretação complexas, não existindo limiar nítido entre a contribuição da mineralização dos nutrientes, a partir da decomposição da palhada da cultura antecessora e que recebeu a adubação antecipada, e a contribuição da disponibilidade residual dos nutrientes fornecidos antecipadamente, através da adubação de semeadura da mesma cultura antecessora. Assim, trabalhos de pesquisa agronômica envolvendo estudos sobre adubação de agroecossistemas devem ser incentivados. 


\section{REFERÊNCIAS BIBLIOGRÁFICAS}

AGRAWAL, B.L.; SIAME, J.A.; UPRICHARD, G.T. Status of finger millet (Eleusine coracana Gaertn.) in Zambia. In: RILEY, K.W.; GUPTA, S.C.; SEETHARAM, A.; MUSHONGA, J.N. Advances in small millets. New York: International Science Publisher, 1994. cap. 2, p.21-28.

BATAGLIA, O.C.; MASCARENHAS, H.A.A.; MIYASAKA, S. Nutrição mineral da soja. In: A Soja no Brasil Central. Campinas, FUNDAÇÃO CARGILL, 1977. cap. 3, p.55-84.

BERLATO, M.A. Bioclimatologia da soja. In: MYIASAKA, S.; MEDINA, J.C. (Ed.) A Soja no Brasil. Campinas: MYIASAKA, S.\& MEDINA, J.C., 1981. p.175-84.

BRASIL Ministério da Agricultura. Regras para análise de sementes. Brasília: LANARV/SNDA, 1992. 365p.

CÂMARA, G.M.S. Nitrogênio e produtividade da soja. In: CÂMARA, G.M.S. Soja: tecnologia da produção II. Piracicaba: ESALQ/LPV, 2000. p.295-339.

CONAB Área, produção e produtividade de soja, safra 2002/2003. http://www.conab.gov.br/download/safra/safra20032004lev04.pdf (30 de Abril de 2004). 
CORDEIRO, D.S. Efeito de adubação NPK na absorção, translocação e extração de nutrientes pela soja (Glycine max (L.) Merrill). Piracicaba, 1977. 143p. Tese (Doutorado) - Escola Superior de Agricultura “Luiz de Queiroz”, Universidade de São Paulo.

EMPRESA BRASILEIRA DE PESQUISA AGROPECUÁRIA. Centro Nacional de Pesquisa da Soja. Cultivares de soja 2000/2001. Londrina: Embrapa, 2000. 48p.

ESTEVES, J.A.F. Produção de soja em função da antecipação da adubação fosfatada e potássica em semeadura direta. Botucatu, 2000. 107p. Dissertação (Mestrado) Faculdade de Ciências Agronômicas, Universidade Estadual Paulista.

FOOD AND AGRICULTURE ORGANIZATION Production yearbook. Roma: FAO, 1999. v.53, p.85.

FOLLET, P.L.; MURPH, L.S.; DONAHVE, R.L. Fertilizers \& Solos Amendments. Prentice Hall, Englewood Cliffs, N.J., 1981.

FRANCISCO, E.A.B. Antecipação da adubação da soja na cultura de Eleusine coracana (L.) Gaertn., em sistema de plantio direto. Piracicaba, 2002. 55p. Dissertação (Mestrado) - Escola Superior de Agricultura "Luiz de Queiroz", Universidade de São Paulo.

KURIHARA, C.H.; MAEDA, S.; HERNANI, L.C. Adubação de manutenção para a cultura da soja no sistema plantio direto. Dourados: EMBRAPA, 1998. p.1-5 (Comunicado Técnico, n. 32). 
LANTMANN, A.F.; CASTRO, C. Manejo da fertilidade do solo e da nutrição da soja para a máxima produtividade. In: WORLD SOYBEAN RESEARCH CONFERENCE 7., INTERNATIONAL SOYBEAN PROCESSING AND UTILIZATION CONFERENCE 4., CONGRESSO BRASILEIRO DE SOJA 3. EMBRAPA, Foz do Iguaçu: Proceedings, 2004. p. 1269-1274.

LINGE GOWDA, B.K.; ASHOK, E.G.; CHANDRAPPA, M. An overview of technology transfer and its impact on finger millet production in Karnataka. In: RILEY, K.W.; GUPTA, S.C.; SEETHARAM, A.; MUSHONGA, J.N. Advances in small millets. New York: International Science Publisher, 1994. cap.40, p.501-518.

LOPES, A.S. Manual de Fertilidade do Solo. São Paulo: ANDA/POTAFÓS, 1989. 155p.

MALAVOLTA, E. Manual de química agrícola. São Paulo, Editora Agronômica Ceres, 1976. 528p.

MALAVOLTA, E. Elementos de nutrição mineral de plantas. São Paulo, Editora Agronômica Ceres, 1980. 251p.

MALAVOLTA, E. Absorção e transporte de íons. In: FERRI, M.G. Fisiologia vegetal. 2.ed. São Paulo: EPU, 1985. p.77-114.

MASCARENHAS, H.A.A. Acúmulo de matéria seca, absorção e distribuição de elementos, durante o ciclo vegetativo da soja. Campinas: Instituto Agronômico, 1973. 47p. (Boletim Técnico, 6).

MASCARENHAS, H.A.A.; TANAKA, R.T.; AMBROSANO, E.J. O fósforo no solo e na soja. Revista de Agricultura, v.68, n.1, p.77-78, jun.1993. 
MASCARENHAS. H.A.A.; DEMATÊ, J.D.; MIYASAKA, S.; IGUE, T. Estudos preliminares sobre adubação econômica da soja (Glycine max (L.) Merrill) na região da Alta Mogiana, em Latossolo Roxo e Latossolo Vermelho-Amarelo fase arenosa. Campinas: Instituto Agronômico, 1971. 7p.

MASCARENHAS, H.A.A.; BATAGLIA, O.C.; IGUE, T.; TISSELLI FILHO, O.; MIRANDA, M.A.C. Efeito residual de adubação em soja. Campinas: Instituto Agronômico, 1975. 13p. (Boletim Técnico, 24).

MASCARENHAS, H.A.A.; MIYASAKA, S.; BRAGA, N.R.; MIRANDA, M.A.C.; TISSELLI FILHO, O. Calagem e Adubação da Soja. In: FUNDAÇÃO CARGILL. A Soja no Brasil Central. Campinas: FUNDAÇÃO CARGILL, 1977. cap. 4, p.85138.

MASCARENHAS, H.A.A.; BULISANI, E.A.; MIRANDA, M.A.C.de; PEREIRA, J.C.V.N.A.; BRAGA, N.R. Deficiência de potássio em soja no Estado de São Paulo: melhor entendimento do problema e possíveis soluções. Informações Agronômicas. n.42. p.1-3, jun. 1988.

MASCARENHAS, H.A.A.; BATAGLIA, O.C.; IGUE, T.; TISSELLI FILHO, O.; MIRANDA, M.A.C.de; PEREIRA FILHO, A.W.P. Efeito Residual de adubação na produção de soja. Campinas: Instituto Agronômico, 1981. 18p. (Boletim Técnico, 24).

MATHAN, K.K Direct effect of magnesium, potassium and calcium on yield, protein content and Mg uptake by finger millet (Eleusine coracana) in acid soil. Indian Journal of Agronomy, v.40, n.4, p.609-612, dec. 1995. 
MITARU, B.N.; KARUGIA, J.T.; MUNENE, C. Finger millet production and utilization in Kenya. In: RILEY, K.W.; GUPTA, S.C.; SEETHARAM, A.; MUSHONGA, J.N. Advances in small millets. New York: International Science Publisher, 1994. cap.21, p.247-254.

MNYENYEMBE, P.H. Past and present research on finger millet in Malawi. In: RILEY, K.W.; GUPTA, S.C.; SEETHARAM, A.; MUSHONGA, J.N. Advances in small millets. New York: International Science Publisher, 1994. cap.3, p.29-37.

MULATU, T.; KEBEDE, Y. Finger millet importance and improvement in Ethiopia. In: RILEY, K.W.; GUPTA, S.C.; SEETHARAM, A.; MUSHONGA, J.N. Advances in small millets. New York: International Science Publisher, 1994. cap.5, p.51-59.

MUSHONGA, J.N.; MUZA, F.R.; DHLIWAYO, H.H. Development, current and future research strategies on finger millet in Zimbabwe. In: RILEY, K.W.; GUPTA, S.C.; SEETHARAM, A.; MUSHONGA, J.N. Advances in small millets. New York: International Science Publisher, 1994. cap.1, p.11-19.

NOVAIS, R.F.; KAMPRATH, E.J. Phosphorus supplying capacity of previously heavily fertilized soils. Soil Science Society of America Journal, v.42, p.231-35, 1978.

ODELLE, S.E. Improvemente of finger millet in Uganda. In: RILEY, K.W.; GUPTA, S.C.; SEETHARAM, A.; MUSHONGA, J.N. Advances in small millets. New York: International Science Publisher, 1994. cap.8, p.75-83. 
OLIVEIRA, F.A. Desenvolvimento vegetativo e nodulação de plantas de soja em função de nitrogênio e fósforo aplicados na semeadura em condições controladas. Piracicaba, 1996. 85p. Dissertação (Mestrado) - Escola Superior de Agricultura “Luiz de Queiroz”, Universidade de São Paulo.

PANIZZI, A.R. Manejo integrado de pragas da soja no Brasil. In: CROCOMO, W.B. (Ed.). Manejo integrado de pragas. São Paulo: UNESP, 1990. cap.15, p.293-321.

PILANE, M.S.; SALVE, R.B.; PAWAR, V.S.; BHOI, P.G. Response of fingermillet (Eleusine coracana) varieties to nitrogen and phosphorus. Indian Journal of Agronomy, v.42, n.4, p.637-640, dec. 1997.

PRASADA RAO, K.E.; WET, J.M.J. de; GOPAL REDDY, V.; MENGESHA, M.H. Diversity in the small mullets collection at Icrisat. In: RILEY, K.W.; GUPTA, S.C.; SEETHARAM, A.; MUSHONGA, J.N. Advances in small millets. New York: International Science Publisher, 1994. cap.27, p.331-346.

RAIJ, B. Van; MASCARENHAS, H.A.A. Calibração de potássio e fósforo em solo, para a soja. In: CONGRESSO BRASILEIRO DE CIÊNCIA DO SOLO, 15. Campinas: Sbcs, 1975. p.309-315.

RAO, K.L.; RAO, C.P.; RAO, K.V. Response of finger millet (Eleusine coracana L. Gaertn) cultivars to nitrogen under rainfed conditions. Indian Journal of Agronomy, v.34, n.3, p.302-306, 1989.

RAO, K.L.; RAJU, D. V.N.; CHITKALA DEVI, T.; RAO, C.P.; RAO, T.K.V.V.M. Effect of level and time of nitrogen application to fingermillet (Eleusine coracana) under rainfed condition. Indian Journal of Agronomy, v.36 (Suppl), p.91-95, 1991. 
ROSOLEM, C.A. Adubação potássica em semeadura direta. In: SIMPÓSIO SOBRE FERTILIDADE DO SOLO EM PLANTIO DIRETO. Dourados: EMBRAPA Empresa Brasileira de Pesquisa Agropecuária, 1997. p.59-75.

SHERCHAN, K.; BANIYA, B.K. Finger millet in Nepal: overview, progress, problems and prospects. In: RILEY, K.W.; GUPTA, S.C.; SEETHARAM, A.; MUSHONGA, J.N. Advances in small millets. New York: International Science Publisher, 1994. cap.13, p.123-138.

SUBBA RAO, A.; PRABHU, U.H. Effect of fertilizer and variety on nutritional quality of finger millet (Eleusine coracana) straw. Indian Journal of Agricultural Sciences, v.66, n.4, p.240-242, apr. 1996.

SUBBA RAO, A.; PRABHU, U.H.; SAMPATH, S.R.; OOSTING, S.J. Variation in chemical composition and digestibility of finger millet (Eleusine coracana) straw. In: RILEY, K.W.; GUPTA, S.C.; SEETHARAM, A.; MUSHONGA, J.N. Advances in small millets. New York: International Science Publisher, 1994. cap.25, p.297307.

TANAKA, R.T.; MASCARENHAS, H.A.A.; BORKERT, C.M. Nutrição mineral da soja. In: SOUZA, P.I.M.; ARANTES, N.E. Cultura da soja nos cerrados. Piracicaba: Potafós, 1993. p.105-113.

VITTI, G.C.; LUZ, P.H.C. Manejo químico do solo para alta produtividade da soja. In: SIMPÓSIO DA CULTURA DA SOJA, Piracicaba, 1998. Soja: tecnologia da produção. Piracicaba: G.M.S. CÂMARA, 1998. p.84-112. 
APÊNDICES 
APÊNDICE 1. Valores dos quadrados médios para as características agronômicas analisadas

\begin{tabular}{lcccccccccc}
\hline $\begin{array}{l}\text { Fonte de } \\
\text { variação }\end{array}$ & G.L. & P.M.S. & A.F.P. & E.F & AC & H.V. & N.R.P. & N.V.C.P. & N.T.V. & N.T.G.P. \\
\hline Bloco & 2 & 1064600,8344 & 98,7778 & 0,0486 & 0,5278 & 2437,6441 & 0,1186 & 0,3286 & 26,4036 & 202,0386 \\
Tratamento & 11 & 1935238,8351 & 7,8081 & 3,7059 & 0,7551 & 259,7647 & 0,1894 & $1,7917 *$ & $53,9335 *$ & $306,1900 *$ \\
Resíduo & 22 & 1242013,9108 & 10,1111 & 3,8216 & 0,4672 & 190,7698 & 0,4362 & 0,8780 & 17,2033 & 79,0547 \\
\hline
\end{tabular}

APÊNDICE 2. Valores dos quadrados médios para as características agronômicas analisadas

\begin{tabular}{lcccccccccc}
\hline \multicolumn{1}{c}{$\begin{array}{c}\text { Fonte de } \\
\text { variação }\end{array}$} & G.L. & P.T.G.P. & V. 3 x 3 & V. 3 x 2 & V. 3 x 1 & V. 2 x 2 & V. 2x 1 & V. 1 x 1 & P.A. & P. 1000 \\
\hline Bloco & 2 & 6,5134 & 13,6144 & 0,6886 & 0,2769 & 1,7053 & 0,0533 & 0,8503 & 80154,3348 & 261,6659 \\
Tratamento & 11 & $6,0406 *$ & $18,4063 *$ & 1,6002 & 0,7038 & $4,8135 *$ & 0,3355 & 0,2002 & 42489,5310 & 16,3223 \\
Resíduo & 22 & 1,4418 & 4,3423 & 2,2701 & 0,5757 & 0,7250 & 0,3997 & 0,2785 & 27673,6422 & 21,7069 \\
\hline
\end{tabular}

